Universidad de Lima

Facultad de Comunicación

Carrera de Comunicación

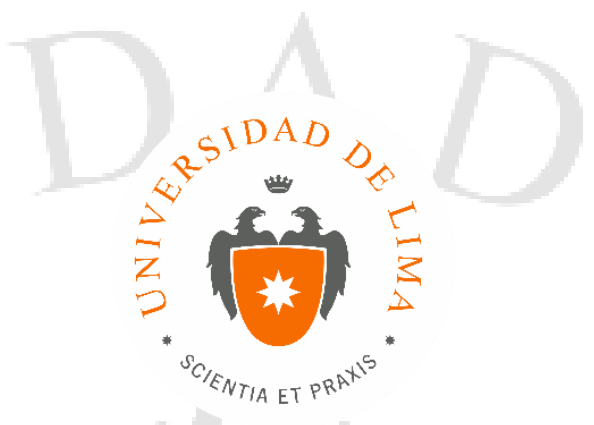

\title{
EL TUTOR SILENCIOSO: LA VENGANZA EN LAS MUJERES DEL CINE DE PARK CHAN-WOOK
}

Trabajo de investigación para optar el Título Profesional de Licenciado en

Comunicación

\section{Carlos Gustavo Quiroz Figuerola}

Código 20041982

\author{
Asesor \\ Lima - Perú \\ Marzo de 2017
}

Gerardo Arias Carbajal 


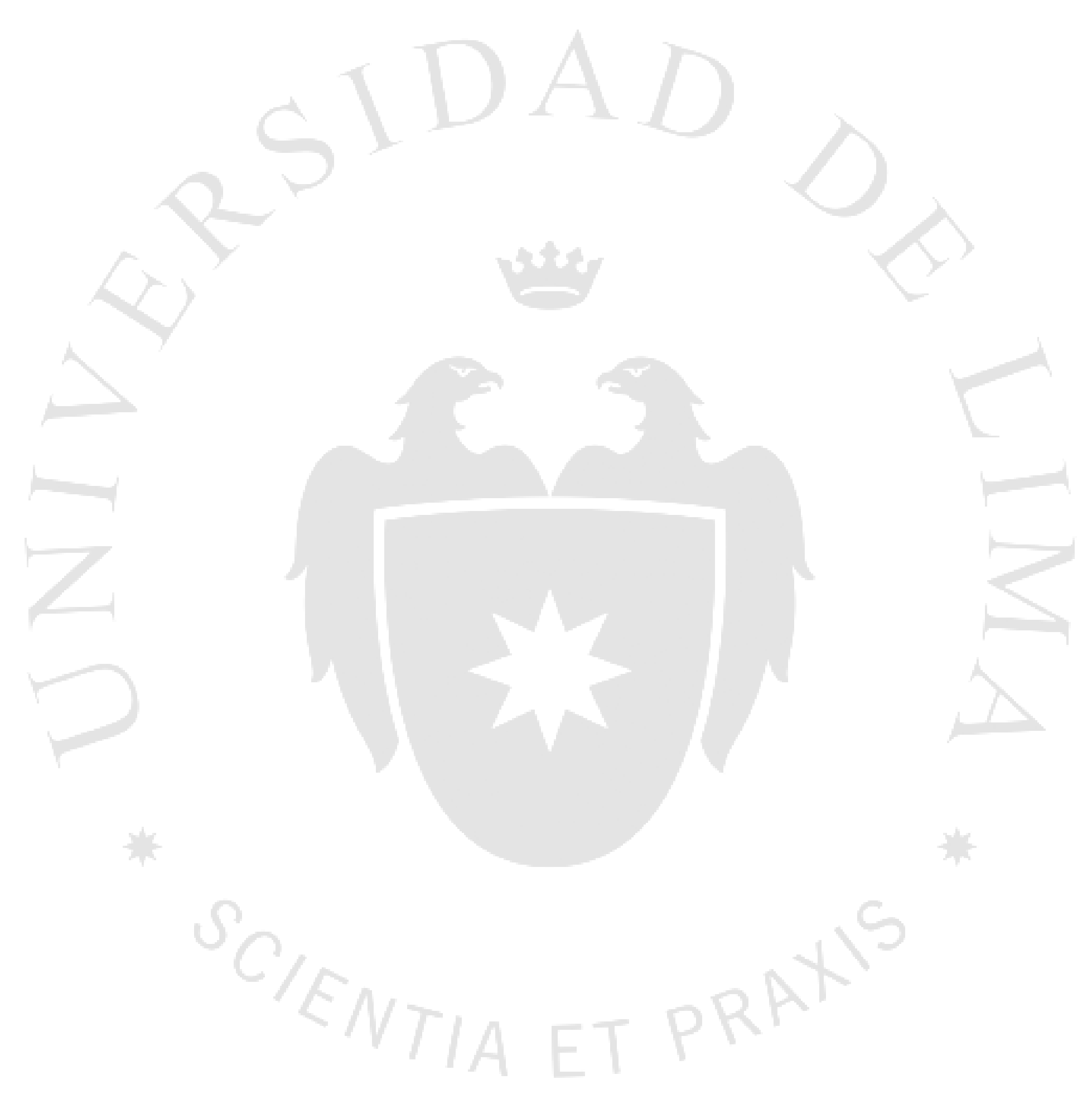




\section{EL TUTOR SILENCIOSO: LA VENGANZA EN LAS MUJERES DEL CINE DE PARK CHAN-WOOK}




\section{SUMILLA -}

El presente artículo discute el tratamiento de la mujer vengativa en el cine de Park Chan-wook a través de tres de sus filmes, Lady Vengeance (2005), Stoker (2013) y The Handmaiden (2016). A través de un análisis de su obra se muestra sus orígenes e importancia dentro de los directores de la Nueva Ola del cine coreano y la predominancia por la representación de la venganza en sus películas, así como su predilección por algunos géneros cinematográficos como el thriller y el melodrama con atribuciones del film noir, sus influencias en el tratamiento del sonido de las J-horror y la herencia de la mujer vengativa que rescata del subgénero de cine fantástico japonés del Kaibyo eiga. Se pone especial énfasis en el proceso y retribución de las mujeres vengativas representadas por el autor; se comprueba la relación de estos elementos con la teoría de Agencia de Anthony Giddens; y, finalmente, se concluye que el recorrido por la venganza y su consumación por las mujeres del cine de Park Chan-wook son los hechos que les permiten el descubrimiento y aceptación de lo que esencialmente las define.

\section{PALABRAS CLAVE:}

Nueva Ola, Nuevo Cine Coreano, venganza, mujer vengativa, agencia, Park Chan-wook. 


\section{ABSTRACT}

This article discusses the treatment of the vengeful woman in the Park Chan-wook cinema through three of his films, Lady Vengeance (2005), Stoker (2013) and The Handmaiden (2016). Through an analysis of his work it shows his origins and the value within the directors of the New Wave of Korean cinema and the predominance by the representation of revenge in his films. It also shows his predilection for some cinematic genres such as the thriller and melodrama with the attributions of black cinema, his influences on the sound treatment of J-horror and the revenge of the vengeful woman he rescues from the subgenre of Japanese fantasy cinema of the Kaibyo eiga. Special emphasis is placed on the process and retribution of women virtual representations by the author, checking the relationship of these elements with the agency theory of Anthony Giddens. Finally, it is concluded that the process of revenge and its consumption by the women of Chan-wook Park film are the facts that allow the discovery and acceptance of what essentially define them.

\section{KEYWORDS}

New wave, new Korean cinema, vengeance, vengeful women, agency, Park Chan-wook. 


\section{A D INTRODUCCIÓN}

\section{Marco teórico}

Dado que la presente investigación está centrada en el estudio de la venganza femenina en el cine de Park Chan-wook, será necesario circunscribir los parámetros que sirvan de ejes conceptuales sobre los que apoyar la lectura del análisis. Lo primero es definir el cine coreano en temporalidad, temáticas y evolución para ubicar al director dentro de contexto. En el texto El Cine Coreano Contemporáneo, María del Pilar Álvarez da un resumen sobre los inicios de la industria surcoreana:

"Los orígenes del cine coreano se remontan a la época colonial (1910-1945). Si bien éste fue presentado por primera vez al público mediante un aviso comercial hacia finales de la dinastía Joseon (1392-1910), es bajo el gobierno japonés cuando la industria cinematográfica coreana se desarrolla" (Álvarez 2012: 50).

Especificando un periodo temporal, señala la tendencia de los primeros filmes que se realizaron: 
"Desde el comienzo, su historia estuvo signada por la coerción y por encontrar en esos marcos de censura espacios para la creación, renovación y apelación de lenguajes simbólicos de denuncia" (Álvarez 2012: 50).

En los primeros años posteriores a la colonización japonesa, el cine coreano se avocó a representar historia de héroes que lucharon por la libertad del país. Luego, el conflicto de las dos Coreas disminuyó considerablemente la producción del país debido a los problemas sociales y políticos que enmarcaron el conflicto, que trajeron consigo un saldo de dos millones de muertos, hambruna y crisis socioeconómica. Ello llevó a una renovación en la cinematografía surcoreana como señala la ya citada Álvarez:

"Sin embargo, el fin de la guerra reactivó y renovó la industria cinematográfica. Desde 1955 hasta 1972, el cine encontró su Edad de Oro en la producción de melodramas desconocidos en el mercado occidental" (Álvarez 2012: 51).

Las temáticas de estos filmes de renovación giraron en torno a los traumas de la postguerra:

"La inserción de la mujer en el mercado laboral, la desestructuración de la familia tradicional, las nuevas dinámicas entre el espacio público y el privado, el mundo rural y el urbano, la expansión de valores "occidentales" y patrones de consumo desconocidos hasta ese momento" (Álvarez 2012: 51).

Los años siguientes estuvieron marcados por las políticas autoritarias de Park Chung-hee (1961-1979), que se caracterizó por aumentar los niveles de censura y mostrar poco interés en el desarrollo de la industria cinematográfica del país, lo cual produjo una notable disminución del cine coreano durante esos años hasta principios de la década de los noventa.

A mediados de la década de los noventa el país entero sufre una auténtica revolución en lo político y económico que trae consigo un nuevo surgimiento de su cine, sobre todo después de la crisis de 1997, lo que hace que muchos especialistas definan esos años como el inicio de la "Nueva Ola" del cine coreano. Para Garcelán y Fernández (2011), esta reactivación del cine coreano se basó en ciertas claves: 
a) La apertura democrática: en 1993 se dan las primeras elecciones democráticas después de casi 40 años de dictadura. Bajo una nueva constitución con leyes que permiten la libertad de pensamiento, se establece la inclusión de una cuota de pantalla para proteger la industria nacional frente a la enorme industria de Hollywood. Con ello se activa la cinematografía nacional.

b) La aparición de inversiones procedentes de las grandes empresas privadas: los llamados 'chaebol'. Las inversiones de los grandes conglomerados de empresas transforman la estructura del negocio del cine que existía hasta ese momento.

c) La formación de nuevos talentos en la dirección: la llamada Nueva Ola de directores procedentes de la Korean Academy of Films Arts. Por lo general, estos nuevos realizadores reciben formación en aulas universitarias y combinan sus estudios entre Corea y el extranjero.

d) La creación del Festival Internacional del Cine de Pusán en 1996: un festival que en pocos años logró catapultarse como el más importante de Asia, desplazando al Festival de Tokio o al Filmarts.

e) Apoyo institucional: la creación de la Motion Pictures Promotion Corporation (MPPC), en 1999 sucedida por la Korean Film Council (KOFIC), entidades cuyo trabajo se extiende en dos sentidos: proteger y ayudar a la producción de cine coreano; y fomentar su conocimiento fuera de sus fronteras, para propiciar muestras, ciclos, etc., de cine coreano por todo el mundo.

Estas claves son la aparición de hechos importantes que dieron condiciones favorables para que se pueda consolidar la Nueva Ola de directores en el Cine Coreano. Realizadores que se han movido en la diversa variedad de los géneros, elaborando estéticas sofisticadas y tratamientos acordes a sus problemáticas contemporáneas. Dentro de las tendencias de estos nuevos directores se destaca el tratamiento de la venganza, por ser la temática argumental predilecta en el cine de Park Chan-wook.

Hay que comenzar por reconocer de dónde son originarios los argumentos cinematográficos, y por reconocer cada temática con una estructura característica que 
facilite su identificación. Siguiendo esa finalidad, se ha tomado los planteamientos de Balló y Pérez (1999), donde se establece que muchos de los argumentos cinematográficos provienen de las narraciones de la mitología griega, incorporándolos como una narrativa germinal que se apoya en el legado anterior para crear nuevos contenidos:

"Las narraciones que el cine ha contado y cuenta no serían otra cosa que un forma peculiar, singular, última, de recrear las semillas inmortales de la evolución de la dramaturgia ha ido encadenando y multiplicando" (Balló y Pérez 1999: 7).

Estos autores, señalan como el principio argumental de la venganza el mito de la Orestíada, donde se narra la historia de Orestes que busca venganza por la muerte de su padre. De allí se extrae la estructura que marca en gran medida los relatos de venganza mostrados en el cine, cuyo género predilecto es el western. El tema atrajo los ánimos de los directores de la Nueva Ola a construir relatos que parten de la vendetta como lo hace el western, mostrando el mismo ímpetu en desarrollar diversos argumentos en torno a la venganza, innovando en la narración con giros inesperados en las historias de sus personajes. Otra característica es la influencia que los directores surcoreanos tienen de las películas denominadas J-horror (Japanese horror), cintas que tuvieron su apogeo a finales de la década de los noventas y los primeros años de los 2000, que marcaron su tendencia por el cine de fantasmas y poltergeists en el género del horror. Directores como Ahn Byeon-ki utilizan las estructuras narrativas de los relatos de espectros vengativos del cine japonés, con una finalidad comercial que ayudó al despegue del Nuevo Cine coreano, como afirma Ian Conrich (2010).

Gran parte de las temáticas en las películas Park Chan-wook giran alrededor de la venganza y son tratadas desde diferentes perspectivas. Su trabajo sobre esta temática es tal vez uno de los más dedicados, debido a que la explora desde las trasgresiones personales los traumas históricos y sociales donde se desarrollan sus personajes, como lo infiere Steve Choe (2010). Choe señala, respecto de la Trilogía de la Venganza, compuesta por Symphaty for Mr. Vengeance (2002), Old Boy (2003) y Lady Vengeance (2004), las diferentes lógicas que se abren en la venganza, unas dictadas por las ansias del castigo y retribución, y otras, destacadas por el autor, por la posibilidad del perdón. Sobre las posibilidades de castigo y retribución se hace un comparativo sobre las características al representar la venganza en el cine Park Chan-wook que menciona Kim 
Kyung-hyun (2006). Por el lado de la posibilidad de perdón, se ha hecho una extensión de lo afirmado por Choe en las lógicas de la venganza en los personajes femeninos de Park Chan-wook; ya que se señala la posibilidad del descubrimiento y aceptación de lo que realmente las define.

El papel de los personajes femeninos en torno a la venganza en las películas del realizador surcoreano es un tema que va tomando cada vez más relevancia, marcando una tendencia a colocarlas como un eje central dentro de sus tramas. Son tres las realizaciones del director en donde la mujer toma un rol protagónico y sobre ellas girará el análisis de la investigación: Lady Vengeance (2003); Stoker (2013), su primera realización en suelo norteamericano; y su último estreno, The handmaiden (2016). Las tres producciones giran en torno a la mujer y la venganza, una más acentuada que las otras, pero que encuentran sus influencias en la tradición de la mujer vengativa del cine japonés de los años sesenta, precisamente en el subgénero del Kaibyo eiga ${ }^{l}$; las tres narran el retorno desde la muerte, como un espectro en forma de gato, de la mujer para vengarse de los hombres que las han asesinado; en las tres esto les acarrea desgracia a ellas y a sus allegados. Esto le da diversas facetas al tema de la mujer vengativa que se acomoda dentro de diversos géneros cinematográficos. Se pretende por ello analizar cómo se incorpora la venganza dentro de los diversos géneros tomando como referencia las teorías de Rick Altman (2000) y Martin Rubens (2000) sobre la diversidad, características y evoluciones de los géneros. Se intentará remarcar las preferencias de nuestro autor por el thriller y el cine negro, sin dejar de utilizar elementos western y el terror.

Otro de los objetivos que se pretende tratar es la influencia del concepto del cine japonés de la mujer vengativa en las películas de Park Chan-wook es, debido a que constituye un antecedente en el tratamiento de cómo la mujer es empujada a la violencia a causa de una sociedad patriarcal abusiva, en donde la mujer es usada para fines truculentos. Esto puede verse en Lady Vengeance y The Handmaiden, así como en la creación de atmósferas fantásticas en la transición de cambio del personaje femenino en Stoker. Estas influencias tienen su origen en la transnacionalización del concepto de la mujer vengativa, que proviene del Japón en la tradición cultural asiática.

\footnotetext{
${ }^{1}$ Cine fantástico que gira en torno al mundo samurái y nace de la influencia de los relatos de la tradición oral, teniendo como hito literario en el teatro Kabuki: Hana no saga nekomata soshi (1853), de Segawa Joko III (Balló y Pérez, 1995: 7).
} 
Respecto de la elección del concepto de la mujer vengativa de la tradición japonesa del Kaibyo eiga como una influencia importante en el cine de Park Chan-wook, cabe resaltar que las mujeres en sus películas no son parte de una fantasía espectral, sino que se desenvuelven en la representación de una realidad cotidiana, sin que este detalle haga perder su relación con las mujeres espectrales del cine japonés, ya que conservan el vínculo de ser personajes transgredidos por el injusto y poderoso: el hombre. Las sociedades orientales del Asia se han caracterizado por ser predominantemente patriarcales, y Corea del Sur no ha sido la excepción, sobre todo por haber sido colonia de una de las culturas más machistas de ese continente, la japonesa, por más de cincuenta años. Las mujeres de Park Chan-wook se abren un camino dentro de esas sociedades por medio de la venganza, y la violencia suele ser la herramienta para construirse una identidad.

La capacidad de actuar en contra de sus trasgresores en medio de una sociedad que las subyuga para construirse una identidad se analizará bajo el concepto sociológico de agencia. Este concepto se ha tomado de la teoría estructuralista de Anthony Giddens (1995) que remarca al individuo como ser con la libertad de actuar y dar forma a la sociedad. El trabajo mostrará cómo las mujeres del cine de Park en su tránsito por la venganza construyen una agencia que las llevará, independientemente de la violencia con la que se consuma, al descubrimiento y aceptación de ellas mismas. 


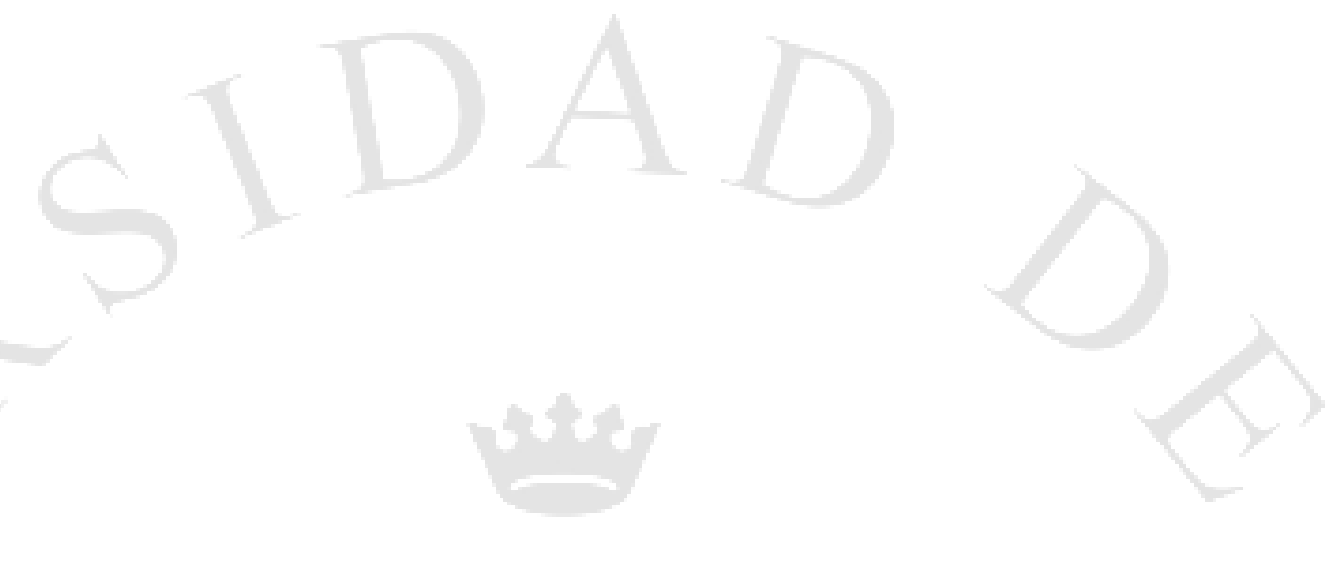

El presente trabajo de investigación propone un análisis de contenido en las películas del director surcoreano Park Chan-wook, tomando como objeto principal, el estudio de los filmes donde la temática de la venganza sea lo relevante $\mathrm{y}$, sobre todo, donde sean sus personajes femeninos quienes la ejecutan. Siguiendo ese criterio, la investigación concentra su análisis principalmente en tres películas de la filmografía del director: Lady Vengeance, Stoker y The Handmaiden. La selección de estos tres filmes cumple con los criterios con que se ha delimitado la presente investigación: tratan de la venganza y los personajes principales son mujeres que la llevan a cabo. Asimismo, estos elementos son primordiales para tratar el objetivo principal de la investigación: la venganza como vehículo hacia la aceptación en las mujeres del cine de Park Chan-wook.

En el trabajo se utiliza el método deductivo para ubicar y contextualizar la obra del director dentro del cine coreano, ya que es parte de la denominada Nueva Ola del Cine Coreano junto a otros directores que siguieron nuevas tendencias y lograron un extraordinario grado de diversidad, que posibilitaron el despegue de la cinematografía de ese país desde finales de los años noventa. Se examina también los géneros predilectos 
de estos realizadores y la hibridación de los mismos como característica principal de su cinematografía. Asimismo, se ubica a Park Chan-wook desde el punto de vista de sus preferencias por el melodrama, el terror, el thriller y el policial; se presta especial atención a la temática argumental de la venganza como característica de la mayoría de sus filmes, tomada principalmente del western.

Una vez que se contextualiza la obra de Park Chan-wook dentro de la cinematografía surcoreana, es necesario caracterizarlo como cineasta y encontrar las características de su filmografía dentro de los géneros que trabaja, así como dentro de las influencias que recibe del cine japonés. Nos parece importante abordarlo principalmente desde el concepto del retorno de la muerte en busca de venganza de las mujeres espectrales del Kaibyo eiga, el subgénero del cine fantástico japonés que se impuso fuertemente en la cinematografía japonesa desde finales de los años cincuenta hasta finales de los años sesenta. El tratamiento del sonido, característico en las cintas del director, tiene una notable influencia de las denominadas J-horror, películas pertenecientes al género fantástico y de terror provenientes del Japón, que tuvieron su apogeo desde finales de los años noventa, y que llamaron la atención de los fanáticos del terror en el ámbito internacional. Las J-horror junto con las filmografías de los directores de la Nueva Ola del cine coreano ayudaron a la internacionalización del cine asiático a finales de los años noventa.

Finalmente, se confronta la narrativa de la mujer vengativa utilizada en la selección de filmes de Park Chan-wook con la teoría sociológica de Estructura-Agencia de Anthony Giddens (1995); sobre todo a partir de la comparación del accionar de sus protagonistas con el proceso de su Modelo Estratificado del Agente. La agencia es la capacidad de acción del individuo y el modelo de Giddens lo explica como un proceso motivacional del individuo que se da de forma inconsciente. Este proceso se compara con las acciones que las protagonistas de los filmes del director para entender su proceso de agencia y cómo ellas construyen su propia agencia. Esto da lugar a una oposición a la sociedad y, como una consecuencia colateral a su accionar, al descubrimiento de su identidad. Lo último es advertido por Giddens dentro de la estructura de su modelo como parte de un proceso que no es esperado, como consecuencias no buscadas de la acción. Esta teoría estructuralista de Giddens será el sustento del objetivo primordial del presente trabajo de investigación: ser el apoyo para reconocer la venganza en los personajes 
femeninos de Parck Chan-wook como un accionar indispensable e inconsciente en el descubrimiento y legitimización de su identidad.

La investigación utiliza una metodología aprehensiva para el análisis de contenido de las tres películas seleccionadas. Se analiza la narrativa y la puesta en escena en la temática de la mujer vengativa, y se destaca el uso de las herramientas que da el lenguaje audiovisual para la construcción de sus personajes y situaciones: el cuidado que se muestra en la composición del encuadre y movimientos de cámara para la creación atmósferas y momentos, que se distingue tanto en la dirección artística como en la dirección fotográfica, como un medio para reforzar la simbología en el comportamiento del personaje, tanto en sus acciones como en la interpretación de su estado emocional. El tema del personaje que toma acciones cuyas consecuencias siempre son fatales será fundamental. 


\section{2 \\ CAPÍTULO I \\ EL CINE COREANO}

\section{1.- Orígenes, evolución y temáticas}

Según Álvarez (2012), la industria del cine coreano cuenta con una larga tradición que se inicia durante los primeros años del siglo XX. Esta tradición estuvo marcada por la represión moral y los marcos de censura a que eran sometidos los coreanos durante los años de ocupación japonesa (1910-1945). A pesar de ello, se encontró en el cine un espacio para la creación, innovación y apelación de lenguajes simbólicos (Álvarez 2012: 50). A mediados de los años veinte las películas coreanas se caracterizaron por tocar temáticas que apelaban a la protesta política contra la dominación japonesa. Esto logró manifestarse como el primer movimiento político de resistencia, conocido como "cine nacionalista" (Álvarez 2012: 52). Estas películas expresaban, de forma sublime e indirecta, el sentimiento de una Corea independiente, sacando cara por una cultura con identidad e historia de más de cinco mil años. El director Na Un'gyu tuvo dos películas que representan el sentimiento de la época: Arirang (1926) y Buscando el Amor (1926).

Desde años antes a la Segunda Guerra Mundial hasta el fin de esta, el régimen japonés tuvo un endurecimiento notable con la población coreana debido a la movilización de tropas para el conflicto. Este suceso dejó marcas traumáticas e imborrables por los reclutamientos forzados, prohibición del idioma coreano, servicio militar obligatorio, imposición del uso de nombres japoneses, esclavitud sexual de mujeres por parte de la armada japonesa, clausura de periódicos, y demás. La edad de oro 
del cine coreano se dio durante los años 1955 hasta 1972; sus producciones se caracterizan por profundizar en la temática de cuestiones de género, en consonancia con el impacto de los traumas de posguerra. Según Álvarez (2012: 51), los años de política autoritaria (durante los cuales vivió Park Chung-hee, 1961-1979), aumentaron los niveles de censura y llevaron al desinterés el desarrollo de la industria cinematográfica, lo cual produjo una caída del cine coreano en los años setentas.

En la década de los noventa, luego de la crisis del FMI de 1997, el Estado junto con los Chaebol (conglomerados coreanos) adoptan una iniciativa política de inversión en la industria cinematográfica que da como resultado un boom en la producción de sus películas, la apertura del mercado internacional y una admiración sin precedentes (Garcelán y Fernández 2011). Gracias al empuje de su industria, el período que cubre los últimos años de los noventa hasta los primeros años del nuevo milenio, el cine coreano se caracterizó por dar paso a un grupo de directores que acusan una nueva mirada en el tratamiento de sus filmes. Están provistos de una estética renovada y una alta sofisticación, y se desplazan entre los diversos géneros, dándole una mayor importancia a problemáticas contemporáneas. Según Garcelán y Fernández (2011), entre los grandes directores que debutan durante esta etapa están Hong Sang-so, Kim Ki-duk, Lee Changdong, Hur Jin-ho, Kwak Jae-young, Song Hae-sung, Bong Joon-ho, Ryoo Seungwan, Song Il-gon, Lee Myung-se y Park Chan-wook. Son estos realizadores son los que configuran la llamada Nueva Ola del cine coreano.

\section{2.- EI Nuevo Cine coreano: encontrando una identidad}

Es inevitable referirse a otros países de la región del oriente asiático cuando se menciona la cinematografía de Corea del Sur. Sobresalen las películas provenientes de China y Japón, que durante muchos años han tenido gran difusión dentro del mercado coreano. Las influencias que pasan de una producción a otra van por los estilos visuales; gracias a técnicas depuradas, las temáticas comunes trascienden las fronteras de un país y se consigue un tratamiento de los géneros con elementos que permean las diferentes producciones.

Si bien entre estas cinematografías comparten algunos elementos entre sí, también muestran acusadas diferencias entre ellos, de manera más acentuada que 
semejanzas, diferencias que delimitan sus cines por los estilos que han logrado popularizar. Para Carlos Gurpegui (2014), estos estilos se basan en períodos históricos y en rasgos culturales de cada país. Mencionando el caso de China, donde uno de los géneros más populares es el wuxia, que son melodramas representados en escenarios históricos de la historia china. La esencia del wuxia, aparte de estar representada en un período histórico concreto, está en los frecuentes combates a espada, que son el principal atractivo. Películas como La casa de las dagas voladoras de Zhang Yimou (2004) y El Tigre y el dragón de Ang Lee (2000), que son las cintas representativas del género.

También Gurpegui (2014) menciona el Jidaigeki, un género que nace en Japón y se ubica en un periodo característico de su historia, que enmarca sus historias en el período Edo (1603-1868), y del que nacen diversos subgéneros en función a su época como el denominado sengoku-jidai, que se representa en la época Sengoku (1467-1568); o en el empleo de la importancia o no de la acción. Ejemplificándolo con el chambaraoriginalmente una onomatopeya usada para el ruido de entrechocar de sables- que es un género de películas jidaigeki, en las que la acción recae en la figura de los samuráis. Una gran gama de películas que representan el mundo samurái entran dentro del género, sobresaliendo las filmes de Kurosawa, Yoji Yamada y Hirokazu Koreeda. También encontramos dentro del género, por los periodos históricos que representan, las cintas que tratan del Kaibo eiga: filmes que tienen como característica estar ubicados en el mundo de los samuráis, pero diferentes del chambara-duelos de espada-, que se centran más bien en la venganza de la mujer desde el Más Allá.

Ambos países vecinos de Corea del Sur han creado géneros a partir de su propia historia, destacando la identidad nacional, tanto sobre su pasado - wuxia en China y el jidaigeki en Japón- como sobre su presente, como señala Gurpegui (2014) es el caso de la figura del cine de yakuzas en Japón o el de artes marciales en China. Esta peculiaridad de brindar a sus cines características que se identifican con sus nacionalidades obedecen a un fin marketero para su distinción y distribución en el mundo occidental. Es de resaltar que, a pesar de contar con más de sesenta años de la llegada de las películas japonesas a Europa y América, sus estudiosos aún no han llegado a un consenso para catalogar de mejor manera la comprensión y categorización de estos cines, y se los generaliza con el simple nombre de "Cine Asiático" (Martínez 2010). 
El caso del cine de Corea del Sur, en el tema de género, es peculiar. A pesar de contar con una rica historia a sus espaldas, que inicia miles de años antes que la separación de las dos Coreas en 1948, la industria surcoreana no concentró sus esfuerzos en la creación de un cine que encuentre sus cimientos en momentos históricos y lleno de nacionalismos como lo hicieron sus vecinos. Los coreanos se caracterizan más bien por los aspectos de su realización y por la hibridación de géneros en sí. Antes de entrar en esta particularidad del cine surcoreano, cabe mencionar algunas producciones que parten de un hecho histórico, pero que no por ello se podría generalizar en un cine con elementos nacionales.

Un ejemplo de lo dicho son producciones como Shiri (1999), dirigida por Kan Je-gyu, y Joint Security Area (2000) de Park Chan-wook. películas que se basan en el conflicto bélico entre las dos Coreas entre los años 1950 y 1953, cuyo verdadero valor está en que encauzaron al cine surcoreano en las premisas del thriller como plataforma dominante en sus ficciones. Por ello logran animar así a los demás realizadores a inmiscuirse en la variedad y mezcla de los géneros, de modo que sea la firma del Nuevo Cine surcoreano. Como asegura Carlos Gurpegui:

Los realizadores y creativos surcoreanos parecen moverse a sus anchas en el complejo terreno de la hibridación genérica mezclando determinados elementos que podríamos denominar canónicos con determinadas piezas de su idiosincrasia nacional convirtiendo en "coreano" determinados géneros (como se citó en Gurpegui, 2014).

La exploración de los realizadores por lo diversos géneros demuestra que el cine surcoreano puede calificarse como una hibridación de los mismos. Si bien hay una preferencia marcada por el thriller en sus producciones, no dejan de lado los melodramas o la comedia romántica, que se mezcla con el drama más duro; todo esto es totalmente posible en el cine coreano. Garcelán y Fernández (2011) citan a Bong Joon-ho, director de Memories of murder (2003) y The host (2007), resaltando el acierto en su manera de ver el cine con lo que podría explicar el gusto por la hibridación de géneros en el cine coreano: 
Lo que yo quiero es usar todo aquello que sea típico y, a su vez, romperlo. Quiero hacerlo usando el realismo coreano, y romper el género, la tradición y la convención. Siempre empiezo con un género, pero al final siempre lo rompo (Garcelán y Fernández 2011).

\subsection{1.- Tendencias de los directores del Nuevo Cine coreano}

La hibridación de géneros es una característica que podría aproximarse a una definición del cine coreano, acentuado por un grupo de directores que conforman la llamada Nueva Ola coreana, junto a Im Kwon-taek -director que da inicio a sus realizaciones durante los años sesentas y que es una figura clave en el cine coreano contemporáneo- son los principales hacedores del resurgimiento del cine de su país que vive una internacionalización a lo largo de los años noventa.

Esta gama de directores brindarán un extraordinario grado de diversidad a su cinematografía, que no podría agruparse en una sola tendencia. Garcelán y Fernández (2011) proponen una clasificación de las diferentes tendencias en los directores de este grupo:

a) Realismo nacional: su interés está en el estudio de los personajes; ponen el énfasis en el ser humano, así como en los problemas sociales y conflictos que vive la comunidad. Alguno de los directores englobados en esta tendencia son Lee Chang-dong (Green fish, 1997; Oasis, 2002); o Im Samg-so (The president's barber, 2005).

b) Intimista o cine de autor: más allá del género se reconocen por su estilo, por sus obsesiones, por su narrativa que los lleva a romper las reglas, reinventándolas o sencillamente, ignorándolas. Así, estaríamos hablando de directores como Kim Ki-duk (Hierro 3, 2004; Aliento, 2007); o Hong Sang-soo (The day a pig fell into the well, 1996; Woman is the future of man, 2004; Tale of cinema, 2005).

c) Cine de género: tendríamos aquí a un grupo compuesto por aquellos realizadores que han apostado por el cine de género (al que han enriquecido gracias a sus planteamientos, estética, técnica narrativa y tendencia a la fusión del melodrama con otros géneros cinematográficos), interesados por el terror, el 
cine negro, el suspense o la comedia, y disfrutan haciendo géneros híbridos. No adoptan narraciones ni conclusiones convencionales pensadas para atraer una reacción favorable de público o crítica. Los realizadores más característicos y conocidos en Occidente serían Park Chan-wook (JSA, 2000; Oldboy, 2003); y Bong Jong-ho (Barking dogs never bite, 2000; Memories of murder, 2003), pero sin olvidarnos de Kim Jee-woon (2 hermanas, 2003), Ryoo Seungwan (City of violence, 2006), Kang Je-gyu (Shiri, 1999; Lazos de guerra, 2004) y otros muchos. 


\section{CAPÍTULO II \\ LA VENGANZA COMO TEMÁTICA ARGUMENTAL}

\section{1.- El patrón argumental de la venganza en la narrativa cinematográfica}

La temática de la venganza en la narrativa del cine, al igual que en todas las artes, tiene su origen en la mitología griega. Como afirman Jordi Balló y Xavier Pérez en La semilla inmortal (1995), el origen de la venganza tiene su inicio en la Orestíada de Esquilo, que narra la venganza de Orestes en contra de su madre Clitemnestra y su amante Egisto, por el asesinato de su padre Agamenón. El relato está compuesto de tres partes a manera de una trilogía: “Agamenón”, "Los coéforas” y “Las Euménides”. Según los autores:

La Orestíada define los momentos básicos del relato, "perfectamente equiparables a los tres actos de la dramaturgia cinematográfica: un hecho inductor, el asesinato; una acción firme por parte del protagonista, la venganza; y una resolución, el juicio, que contempla la posibilidad de la regeneración" (Balló y Pérez 1995: 62).

Como se señala, la trilogía de Esquilo sirve de analogía con los tres momentos de la venganza en la narrativa cinematográfica, y esquematiza el ciclo de la misma. Una cualidad importante en la narrativa de la venganza, que la diferencia de otros patrones argumentales que figuran en La semilla inmortal, es la siguiente: 
El vengador tiene ambivalencia moral porque la sangre derramada tiene su origen en una sangre más antigua. En el ciclo de la venganza el sentimiento de culpa siempre es relativo: todos los personajes tienen alguna razón de peso para haber perpetuado el crimen (Balló y Pérez 1995: 63).

Esto se vuelve un ciclo de violencia implacable, ya que en la historia de la Orestíada también hay hechos importantes que preceden a la muerte de Agamenón. Por un lado, Egisto cuenta con las motivaciones para contribuir al asesinato de Agamenón, puesto que estaría vengando una afrenta familiar del pasado: el asesinato de sus dos hermanos mayores por parte de Atreo, el padre de Agamenón. Por el otro, Clitemnestra estaría vengando el sacrificio de su hija Ifigenia ordenado por Agamenón para obtener un viento favorable para salir hacia Troya antes de la guerra.

Todos estos antecedentes sanguinarios, que también se puede encontrar en la narrativa contemporánea del cine en relación con la temática de la venganza, solo pueden ser detenidos por la intervención divina de Atenea. Este hecho conciliador remarca para Balló y Pérez la importancia dramática de la trilogía, sobre todo en el uso de la narrativa del cine:

Permite ilustrar el paso de la ley tribal de la sangre a la ley de la justicia reglamentada, un tema que hará fortuna en aquellos géneros cinematográficos situados en el finísimo equilibrio entre la ley y el grito atávico de la venganza (Balló y Pérez 1995: 63).

Sin embargo, como aclaran los autores: "el argumento de la Orestíada ha ofrecido un impecable sistema dramático para explicar el argumento de la venganza, aunque la literalidad de su trama haya sido rara vez adaptada" (Balló y Pérez 1995: 63). Hay que resaltar que esto constituye una injusticia del cine con respecto de la Orestíada, "le ha sorbido íntegramente su estructura dramática, pero muy pocas veces le ha hecho explícito en sus películas" (Balló y Pérez 1995: 63). 


\section{2.- El western: el género de la venganza}

Dentro de todos los géneros nacientes a lo largo de la historia del cine es el western el que mejor adoptó la temática de la venganza en su narrativa. Su mejor momento como género fue durante la Edad de Oro del cine norteamericano; sin embargo, su apogeo cayó a finales de los años setenta. El western está representado por icónicas figuras como John Ford, Howard Hawks, John Sturges, Sergio Leone, Clint Eastwood, entre otros. Sus mayores éxitos, por gran parte de estos realizadores, se han debido al tratamiento de la justicia en la figura del vengador de sangre.

Gran parte de las grandes películas del género evocan constantemente al personaje de Ulises. Así lo señalan Balló y Pérez, afirmando lo siguiente:

Toda la segunda parte de la Odisea -la venganza contra los pretendientes- es perfectamente perceptible como base argumental de films que explican el regreso del guerrero a la casa amenazada y planean un enfrentamiento a muerte con quienes representan el nuevo orden (Balló y Pérez 1995: 64).

Para reforzar esa afirmación, hacen una comparación con la película de John Ford La diligencia (1959), en la cual el personaje de Ringo, encarnado por John Wayne, hace un viaje por el desierto para llevar a cabo la venganza por la muerte de sus hermanos. Sin embargo, por más justificada que estén sus acciones, Ringo se mueve al margen de la ley para llevar a cabo su venganza, y puede hacerlo debido a que vive en una sociedad donde el estado de derecho aún lucha por tener una forma constituida.

Como sucede en muchos westerns (Balló y Pérez 1995), dada a la libertad idónea de su dramaturgia y los escenarios salvajes en los que se desarrollan, el argumento del vengador al margen de cualquier orden legal es central en muchas de sus representaciones. Según afirman Balló y Pérez: "Las leyes del Oeste todavía no están escritas, pero forcejean por imponerse" (1995: 28). Se establece así el escenario perfecto para la confrontación de los héroes del western, donde encontrarán el espacio suficientemente amplio para poder consumar sus venganzas, un poco bajo la estructura de la Orestíada, como una respuesta personal a una primera agresión. Así el western se representa como el género idóneo para representar la venganza, ya que proporciona un 
escenario perfecto al margen de la ley, cumpliendo con la estructura narrativa de la temática argumental y evocando a un protagonista con un motivo de venganza. Por supuesto, eso no lo excluye de caer en la confrontación moral o en el error al momento de ejecutarla.

\section{3.- La venganza en el Nuevo Cine coreano}

La violencia explícita mostrada en gran parte de las películas relacionadas con los directores del Nuevo Cine coreano es, en gran medida, la causa de la gran internacionalización que ha tenido en los últimos años su cinematografía. La temática argumental de la venganza ha sido para muchos de estos filmes la plataforma perfecta para exhibir la violencia sin ninguna reserva; de hecho, puede decirse que se han vuelto expertos en su representación. Los cineastas coreanos han aportado un gran número de películas en donde la vendetta está representada desde lo más explícito hasta lo más sutil, con gran talento.

La venganza es el argumento perfecto de estos directores para amoldar y fusionar diversos géneros: aprovechan los múltiples matices de sus personajes para crear atmósferas y escenarios idóneos para la fusión de géneros en el tratamiento de la misma. Las trasgresiones que sufren, las circunstancias que padecen, sus motivaciones iniciales y la tenacidad con que realizan su plan de venganza son cualidades que les permiten insertar características específicas de cada género en la narración de sus historias. Sobre el tratamiento de la venganza en el género, África Sandonis (2012) concluye lo siguiente:

Contextualizando aún más dentro de este código cinematográfico, sin lugar a dudas, la temática más recurrente en las cintas de dicho género es la "venganza". Tratada desde ángulos diferentes, con motivaciones y personajes que poco o nada tienen que ver entre sí, el perfil psicológico de las víctimas, ya sean vengadores o vengados, posee idéntica naturaleza (Sandonis 2012)

El tratamiento de la venganza tiene una gran variedad de matices dentro de la cinematografía coreana, destacada sobre todo en la construcción de sus personajes y los vuelcos narrativos que toman sus historias son poco convencionales. Destacan la complejidad de la historia de Oh Dae-su, interpretado por Choi Min-sik, en Oldboy 
(2003) respecto a la venganza. El film comienza con el encierro inexplicable del protagonista durante trece años para luego ser liberado, lo cual marca el inicio de su plan de venganza contra quién lo mantuvo secuestrado durante tanto tiempo. Oh Dae-su no sabe quién es el autor de su encierro ni la causa; guiado por algunas pistas logra finalmente dar con el culpable. En el desarrollo final de la historia, el protagonista cae en cuenta de que él no es el único que está perpetuando una venganza, sino que también está siendo víctima de Lee Won-jin (Yo Ji-tae). Así la trama se convierte en una historia donde la venganza se libera en ambos sentidos.

Otra de las narrativas truculentas ofrecida por el Nuevo Cine coreano es I saw the devil (2010) del director Kim Ji-woom, donde la venganza viene del lado del antagonista. Kyung-chul es un misógino que mata por puro placer y con desmesurada crueldad; sus víctimas son mujeres que transgrede de todas las formas hasta asesinarlas. La historia cambia cuando asesina a la esposa de Kim Soo-hyeon, quien desencadena un salvajismo y furia tan atroces como las del asesino, con lo cual, desde ese momento, la trama toma el rumbo de la venganza. Los actos del antagonista en su ímpetu de venganza son tan brutales como los de Kyung-chul, con lo cual cambia la direccionalidad de la venganza, que va ahora en sentido contrario: no es el protagonista quien la busca, sino es a él a quien le cae.

La naturaleza de las narraciones en temas de venganza del cine coreano toma forma propia, sin salirse de la estructura de la temática que toma prestada de la Orestíada, pero dándole nuevos matices que descubren nuevas formas de representarlas. Estos ingeniosos tratamientos han logrado con gran éxito la internacionalización de su cine, lo cual se demuestra con la realización de remakes de sus películas producidas en Hollywood y en la exportación de talentosos directores como Park Chan-wook, Kim Jiwoom, entre otros.

\section{4.- Espectros vengativos: Del J-horror al Nuevo Cine coreano}

A finales de la década de los noventas, coincidiendo con el Nuevo Cine coreano, surge una serie de películas provenientes del Japón que revitalizan el género de horror en la escena del cine mundial. Estas cintas, denominadas J-horror, se distinguen por concentrarse en el terror psicológico y en la elaboración de la tensión por medio del 
suspense, incluyendo característicamente fantasmas y poltergeists que retornan de la muerte en pos de venganza, provenientes en su mayoría del folclor japonés.

La acogida de estas cintas por parte de las audiencias de occidente se debió al esfuerzo homogéneo de festivales internacionales especializados en filmes de horror, tanto por el lado norteamericano como por los festivales de Vancouver, Los Ángeles, Chicago y Nueva York; asimismo, por el lado europeo, los festivales de San Sebastián, Porto, Edimburgo y Bruselas; hay que mencionar además la introducción de DVDs enfocados en el género y su continua exposición en las salas de arte.

El éxito de las J-horror abrió las puertas del mercado occidental a otras cinematografías de la región, sobre todo a las que comparten la dedicación por el tratamiento del horror, como es el caso cine coreano, como asegura Ian Conrich: "Korean popular cinema has been able to achieve some organized western exposure on the back of the mainstream success of cult horror films" (Conrich 2010: 107). Esta situación confirma la internacionalización del horror fuera de las fronteras del sureste asiático.

El traslado del horror a lo largo del cine de distintas nacionalidades se debe al reconocimiento de elementos que son parte característica de una cinematografía que pueden ser tomadas en préstamo por otra, sin la necesidad de caer en la copia por darle su propio estilo. Tal es el caso de la película coreana Phone (Ahn Byeong-ki, 2002), cuya trama muestra semejanzas muy evidentes con la película japonesa Ringu (Hideo Tanaka, 1998), en la cual lo medular es la transferencia de una maldición mortal por medio de un objeto tecnológico. En Phone, el objeto es un celular que utiliza la tecnología satelital como medio para expandir su mal, mientras que en Ringu es el uso de la cinta de video que transmite su mal por medio del intercambio para su visualización.

Este es uno de los muchos ejemplos que podríamos mencionar entre los usos y préstamos que la cinematografía coreana toma de la japonesa, sobre todo en los filmes de horror que se extienden a la venganza; préstamos que Conrich explica por los siguientes motivos:

It was perhaps inevitable that elements would seep into Korean horror film seeking commercial recognition. Whilst Asian Gothic narratives have shared, for 
a long time, some common traits, such as the avengings spirit and the haunting figure of the female ghost, the depiction of the look and form associated with $J$ horror by Korean cinema has lead to distinct comparisons (Conrich 2010: 108).

Estas características son consecuencia de un mercado globalizado, donde el encuentro cultural tiene una mayor apertura, pues permite la combinación entre lo nacional y lo importado dentro de todas las cinematografías, y hace que resulte muy difícil la exclusión de ciertas fuerzas culturales. Esto se ve especialmente dentro de los mercados del sureste asiático donde se comparte, como se señala en la cita anterior de Conrich, un cierto grado de afinidad en los elementos culturales compartidos. Es por estas razones que los préstamos del horror que el cine coreano hace del japonés no podrían considerarse imitativos. Shin Jee-young (2005) afirma lo siguiente:

The recent success of Korean films has in large measure been a result of creative interaction between the transnational and the local media, rather than regressive insistance on 'traditional' cultural heritage or a simple adoption and imitation of foreign culture. Equally important, contemporary Korean cinema also shows that the contact between different cultures results in hybridization, not homogenization (Conrich 2010: 28).

Shin Jee-young hace referencia a una de las mejores cualidades con las que cuenta el cine: su capacidad de reinventarse, lo que le demanda estar en constante cambio, ignorando la nacionalidad original de los elementos característicos de un determinado género o estilo en el tratamiento visual. No es que se deje de lado el reconocimiento, pero se presta un mayor interés a los préstamos entre las diversas cinematografías, lo cual generan nuevos usos y estilos visuales. 


\section{DAD \\ CAPÍTULO III \\ PARK CHAN-WOOK EN EL NUEVO CINE COREANO}

\section{1.- Park en la Nueva Ola}

Park Chan-wook es uno de los realizadores de la Nueva Ola del cine coreano que ha contado con más exposición internacional, sobre todo en la primera década del milenio, gracias a sus films Joint security area (2000) y Oldboy (2003). La última de estas fue ganadora como mejor película en el Festival de Cine de Sitges y el gran premio del jurado en el Festival de Cannes, ambos premios obtenidos en el 2004. Con ello se refuerza lo que ya se conocía sobre la creatividad y talento de los autores del cine de esa región.

Joint security area (JSA) fue su primer éxito de taquilla y es la película con la que se lanza a la escena mundial. Con las formas de un thriller, la película narra la investigación de Sophie Jean, interpretada por Lee Young-ae, sobre un tiroteo que se dio en una zona que separa las dos Coreas. Luego destaca en su filmografía la denominada Trilogía de la venganza, que inicia con Symphaty for Mr. Vengeance (2002), una historia que transcurre los senderos del melodrama y el thriller, donde la venganza tiene su origen en la necesidad y las carencias. Luego está Oldboy (2003), que narra el encierro, la venganza y el perdón de Oh Dae.su. Termina con Lady Vengeance (2005), donde narra la venganza de Lee Geun-ja en su búsqueda por el perdón. Park es filosofo de formación, por lo cual agrega a sus personajes una dualidad moral que rinde sus consecuencias más allá de la retribución, e inclina la balanza en favor de las consecuencias negativas que les 
generan. Así lo señala Steve Choe al citarlo en una entrevista que brinda el director a un medio inglés:

In another interview, conducted in London the same year, Park remarked that, "Revenge is something that make you happy and invigorates you only when it is in your imagination, but when it comes to actually realizing this it is never happy and never gives you pleasure. Because it is an act of total stupidity" (Choe 2009: $35)$.

Este concepto de la venganza que maneja el autor se contrapone con el gran cuidado que aplica al representarla y mostrar sus complejidades, tanto en su narrativa como en la composición de su encuadre. Como lo hace en el segmento "Cut" en Three extremes, donde un director de televisión despreocupado llega a su casa para ser víctima, junto con su esposa, de la venganza de un actor desequilibrado que lo acusa de haberlo ofendido y por lo cual busca una retribución. La trama se vale de mucho detalle visual para mostrar los daños físicos y psicológicos que el actor comete contra sus secuestrados. "Cut" goza de una narrativa intrigante, pulcritud en la composición del plano, ayudado por el arte y la fotografía que refuerzan las complejidades tanto de las situaciones como de los personajes del director.

Park es un realizador al que le gusta llevar al límite a sus personajes, poniéndolos en constante conflicto entre lo noble de sus creencias contra la brutalidad con que se manifiestan en sus actos de venganza, empujados por la situación en la que se encuentran o, peor aún, por su propia naturaleza. En Thirst (2009) explora el género fantástico del mundo de los vampiros, colocando a su protagonista, un cura católico que regresa de las puertas de la muerte convertido en vampiro, en la necesidad de matar para poder sobrevivir. Estos actos lo ponen en disyuntiva con sus creencias, debido a lo que tiene que hacer para calmar su eterna "sed".

Stoker (2013) es su primera película fuera de las fronteras de Corea del Sur. La cinta narra la historia de India Stoker, quien pierde trágicamente a su padre el día de su cumpleaños; además de eso, la repentina llegada de su tío Charlie el día del funeral, todo lo cual cambia el rumbo de su vida. El director mueve los hilos de la narración hacía el conflicto que tiene la protagonista al ir descubriendo sus instintos, empujada en todo 
momento por la aparente pasividad de su tío Charlie, el cual sabe que el lazo sanguíneo que comparten va más allá del simple parentesco. Esto lleva la historia de forma simulada por la temática de la venganza, cuyo hecho de consumación es lo que desata por completo la naturaleza asesina de la protagonista. Las escenas truculentas son también indispensables en Stoker, administradas por una narración en ritmo creciente, que ayuda a entender la evolución de los personajes. Lo más impactante se guarda para el final, fiel al estilo de Park Chan-wook.

En el 2016 retorna a su tierra natal para realizar su primera película de época, The handmaiden. En la cinta se cuenta la historia de dos mujeres que son utilizadas por dos tiranos; durante el proceso, ambas mujeres se enamoran y caen en cuenta del engaño del que han sido víctimas. Idean un plan de venganza hacia los dos hombres que las han subyugado, para así poder vivir libremente el amor que sienten la una por la otra. Park Chan-wook muestra en esta película una narración visceral, paradójicamente en un film donde la sangre no cobra el protagonismo de sus anteriores entregas. Resalta ahora el juego del engaño, la seducción y maldad entre sus personajes; eventualmente las relaciones van cambiando hasta contraponerse. Ello se expresa por medio de un uso distante de la cámara, armando atmósferas donde resalta el engaño y la sospecha, usando una cámara detallista en los momentos de intimidad.

Por medio de sus filmes se reconoce el estilo y la calidad del director surcoreano. Queda de manifiesto que la temática de la venganza es su predilecta, la cual aborda desde varios ángulos, partiendo desde cualquier posible circunstancia. Coloca siempre a sus personajes en la ambivalencia moral, confrontándolos entre sus acciones perversas y sus buenas intenciones o creencias. Manifiesta con sus personajes que no siempre es satisfactorio lo que quieren frente a lo que se obtienen, como lo muestran los protagonistas de su Trilogía de la venganza. Acompañado por una técnica que ha ido depurando en el transcurso del tiempo, sus películas lo muestran como un director que no pierde ningún detalle, que elabora la composición del encuadre con el cuidado de un artesano que se preocupa en que nada parezca artificial, que usa transiciones cuidadosamente realizadas para sumergir a la audiencia en las fauces del relato.

Sus primeros trabajos no tuvieron la misma atención que adquirieron las que vinieron a partir de Joint security area en adelante. Sin embargo, eso no lo restringió para 
ser un referente dentro de la Nueva Ola del cine coreano, debido a que desde el año 2000 en adelante, su trabajo ha ido a un ritmo en general creciente. Con cada película su técnica y ritmo de manejo en la narración han mejorado, explotando el contraste de colores y composición en el encuadre, ayudado por la dirección artística y fotográfica. Ha logrado así ganar en los festivales internacionales más importantes, haciéndose un lugar entre los más grandes directores de su nación, junto con realizadores de la talla de Im Kwon-taek, Hong Sang-soo, Boon Joon-ho, Kim Ki-duk o Kim Ji-woon.

\section{2.- La venganza en Park Chan-wook}

Park Chan-wook es uno de los directores que más se ha dedicado a explorar la temática de la venganza en su filmografía y, con ello, es uno de los que ha mostrado más dinamismo en el tránsito entre los géneros para representarla. Desde su éxito con JSA, drama bélico en el que muestra el resentimiento y el trauma de posguerra que existe entre ambas Coreas; en él se narra, a través de la investigación de Sophie Jean, el tiroteo de dos grupos de soldados en la frontera de las dos Coreas, lo cual da pie a la interpretación de que los motivos del tiroteo son propios de la venganza. Hasta el reconocimiento logrado con la Trilogía de la venganza, donde a través de tres historias que se mueven en diferentes géneros, nos muestra lo diverso y multifacético de este vil sentimiento. Como asegura Steve Choe, la venganza en el cine de Park Chan-wook se amolda bajo diferentes lógicas:

"In each of the films of the trilogy revenge is engaged and thematized, yet in the last, as I shall show in a moment, Park offers an interpretation of revenge that opens up a different logic altogether, one dictated less by punishment and payback and more by the possibility of forgiveness" (Choe 2009: 31).

Dentro de la lógica del castigo y retribución que menciona Choe, hay una serie de características importantes que muestra el director en sus realizaciones sobre la venganza que coinciden con lo que postula Kim Kyung-hyun en relación a las características de sus personajes vengativos. Dentro de estas características, se centrará el análisis en las tres de ellas que ayudan circunscribir los parámetros de su accionar vengativo: la primera es que los personajes siempre se mueven al margen de la ley, al igual que los héroes del western, para poder desenvolverse con libertad en sus 
acciones; por el camino de la ley ellos nunca podrían conseguir la retribución que creen merecer.

First, it emphasizes the fact that the heroes and villains operate outside the domain of the law. They mercilessly abduct, kill, blackmail, threat, unleash violence, and engage in series of reprisals without ever even implying the existence of a public judicial system of the kind that typically occupies a central position in dramas dealing with individual liberty and freedom" (Kim Kyung-hyun 2006: 88).

A lo citado hay que agregar que, al ser representados los agentes del orden en las películas de Park, figuran como poco eficientes, incapaces de controlar las circunstancias que lo requieren. En los primeros minutos de Old-boy, en los que se muestra a Oh Dae-su detenido bajo los efectos del alcohol, la policía solo le lanza una advertencia, pero es incapaz de controlarlo, siendo constantemente ridiculizados por el protagonista. También los muestra como sujetos fáciles de engañar, siguiendo pistas falsas, y sin lograr solucionar los casos; contribuyen al perjuicio de los personajes y, a la vez, les dan mayor libertad para desarrollar su venganza.

\section{La segunda característica que se resalta es el carácter exclusivamente} personal de la venganza que buscan los personajes en cuestión. Los personajes de la Trilogía de la venganza buscan su revancha castigando directamente a las personas que les hicieron algún perjuicio, comúnmente un hecho fatal. Si en el desarrollo de sus acciones lastiman o asesinan a otras personas, eso es parte del daño colateral que causan al buscar su objetivo. Sin embargo, las personas externas que sufren parte de las consecuencias de la venganza son parte del entorno del antagonista y son enviados por él para intentar detener o redirigir su avance, como es el caso de Lee Wu-jim en Oldboy. Después de la pelea a punta de martillazos con los secuaces de Cheol-ung (el dueño de la pseudo-prisión donde mantuvieron encerrado al protagonista durante trece años sin darle ninguna explicación), Oh Dae-su camina moribundo por la calle; entonces un desconocido se percata de su estado y lo ayuda subiéndolo a un taxi para que sea auxiliado. Dae-su le da las gracias y el desconocido le devuelve el gesto llamándolo por su nombre. Al saber su nombre, Dae su cae en cuanta de que ese es el hombre que está buscando y está vigilando lo que hace. Ensangrentado y débil, solo le queda ver con impotencia como se aleja por la ventana del taxi. Al final, Wu-jim le revela a Dae-su que 
todo lo que ha hecho para encontrarlo ha sido porque él así lo quiso, como parte de un elaborado plan.

\section{En tercer y último lugar, está el tema del cuerpo como objeto de venganza.}

Todo el simbolismo que conlleva la venganza se manifiesta por las vejaciones que sufre el cuerpo.

Bodily pain is such an important characteristic of Park Chan-wook's trilogy that through this recurring motif, his films achieve what I think are an aesthetics, ethics, and politics of the body. In his films body parts are often dismembered, and human organs such as kidneys or hearts become detached from the human body" (Kim Kyung-hyun 2006: 98).

La afirmación de Kim Kyung-hyun sobre la separación de los órganos del cuerpo llevan a un simbolismo importante de las acciones brutales según cuáles partes del cuerpo son afectadas. Cuando Dae-su localiza a Cheol-ung lo tortura extrayéndole con un martillo gran parte de la dentadura, lo cual se puede leer como un pago por el silencio que guardó al mantenerlo tantos años encerrado; en ese momento le exige que le diga quién fue el que ordenó su cautiverio. En Lady Vengeance la sombra roja sobre los parpados de Geum-ja cambian su rostro durante todo el proceso que la lleva a consumar su venganza. Al final se quita la sombra con la muerte de Mr. Baek, y vuelve a tener el rostro inocente que la caracterizaba de joven. Al final de Oldboy es Dae-su quien se corta la lengua como pago a Wu-jim, por su ofensa del pasado al correr el rumor de la relación que mantenía con su hermana, que fue la causa de su suicidio.

Volviendo al tema del castigo y retribución en las lógicas de la venganza, Choe menciona como un elemento importante de ellas la posibilidad del perdón. Concentra su análisis sobre todo en las motivaciones de Geum-ja en Lady Vengeance para probar su punto. Sobre esa última afirmación, se puede inferir que si se abre la posibilidad del perdón también podrían abrirse otras posibilidades que sean comunes a los demás personajes, incluyendo efectos colaterales que ayuden a definir la esencia del personaje una vez consumada su venganza. Primordialmente la posibilidad se abre en las mujeres del cine Park Chan-wook: el descubrimiento y aceptación de lo que realmente las define. 


\section{3.- La venganza en las mujeres de Park Chan-wook}

Son pocos los directores dentro del Nuevo Cine coreano que han retratado con tanta minuciosidad a la mujer vengativa como lo realizado por Park Chan-wook. Dentro de su extensa filmografía son tres los films que ponen a la mujer en el protagónico de la venganza, lo cual marca una tendencia por el tratamiento de la figura femenina, y lo diferencia de otros directores de la Nueva Ola que se ubican dentro de la temática. En la mayoría de los casos estos personajes son incluidos en roles secundarios, y sirven de motivaciones para la venganza y no tanto como ejecutoras de la misma. Otra razón que destaca el trabajo del director, en torno al tema de la mujer vengativa, es la importancia que le da a la subjetividad de estos personajes, confrontando sus apacibles personalidades con el sadismo truculento de sus acciones; este dilema al que los somete es uno de los principales hilos narrativos en sus historias.

Es necesario partir de la importancia que el autor presta a orientar sus historias por la subjetividad de sus personajes femeninos, lo cual se enlaza con la afirmación de Steve Choe de la necesidad de que estos personajes descubran y acepten lo que realmente las define en los films de Park Chan-wook (por ejemplo, el perdón a sus pecados que busca Geum-ja al ejecutar su venganza que señala Choe). Comenzando por la importancia del hecho de la venganza en la película, hasta el punto de ser mencionado por la narradora (la voz de su hija siendo una adulta): "Lee Geum-ja, en su juventud, cometió un gran error... y usó a los demás para lograr sus propias metas. Sin embargo, aun así, no pudo encontrar la redención que deseaba". También se puede deducir por lo afirmado por Jonathan Romney:

And that a woman seeking both revenge and atonement for her sins, in Park's last film, Symphaty for Lady Vengeance, 2005 (being released in the US this month simply as Lady Vengeance), will still feel unconsoled even after organizing the ritual slaughter of her foe (Romney 2006: 272).

Además, la búsqueda del perdón se representa en diferentes momentos del film, como cuando Geum-ja pide perdón a los padres de Won-mo hasta el punto de cortarse un dedo, generando el espanto de la pareja; en la búsqueda de su hija, la cual siente que la abandonó cuando fue a prisión, para pedirle perdón; al enterarse de que Mr. Baek es 
un asesino de niños en serie, y reúne a los padres de las víctimas para que participen de la venganza. En el grupo de padres estaban los padres de Won-mo, el pequeño que supuestamente asesinó. Ahora, en la búsqueda de la venganza en las mujeres de Park se abre la posibilidad del reconocimiento y aceptación de lo que las define. La venganza funciona como un espejo en el que estos personajes se observan, reconocen sus defectos y aceptan quiénes son. Al consumar Geum-ja su venganza y ser perdonada por su hija, cae en cuenta de que no es la persona en la que cree se ha convertido, sino que aún conserva buenos sentimientos que afloran por la bondad y el amor por su hija, emociones que ella pensaba había perdido por los errores que cometió en su vida. Reconoce finalmente el amor por su hija con la abnegación de una madre.

En Stoker la posibilidad del reconocimiento de la esencia del personaje se hace más evidente. Al inicio del film, India Stoker es una joven introvertida y lleva una relación disfuncional con su madre. Con la muerte de su padre y la intrigante llegada de su tío Charlie, la técnica de Park Chan-wook comienza a enfocarse en jalar el hilo para desenredar lentamente la madeja que oculta el misterioso comportamiento de su protagonista. Lo que guarda dentro de sí y lo que su inquietante tío Charlie sabe, la empuja a que ella deduzca qué es lo que verdaderamente los hace familia: la liberación del instinto asesino de los Stoker. Si bien su tío Charlie es el que funge de tutor silencioso para que libere su esencia retenida, irónicamente, al asesinarlo en venganza por la muerte de su padre, libera en ella el gusto por matar. Con un enlace entre la primera y última escena, se muestra a India reconociéndose y aceptándose como una asesina a sangre fría, sin tener el menor reparo en hacerlo cuantas veces se lo dicte su maldad recientemente florecida.

Finalmente, la venganza por medio de la sexualidad se muestra en The Handmaiden. En un principio, las protagonistas mantienen la distancia entre ama y doncella, reconociendo cada una sus frívolos intereses. Luego todo cambia por medio de un juego paulatino de seducción entre ambas: las caricias sugerentes y las conversaciones fingidas se convierten una apasionada escena de cama donde ambas desarrollan por completo su amor. Sin embargo, la liberación de este amor no se da hasta el momento en que deciden cobrar venganza contra ambos hombres que las timaron e intentan subyugarlas; es en ese momento cuando las protagonistas aceptan el amor que sienten la una por la otra. Al reconocerse como iguales se dan su amor con la misma intensidad. 


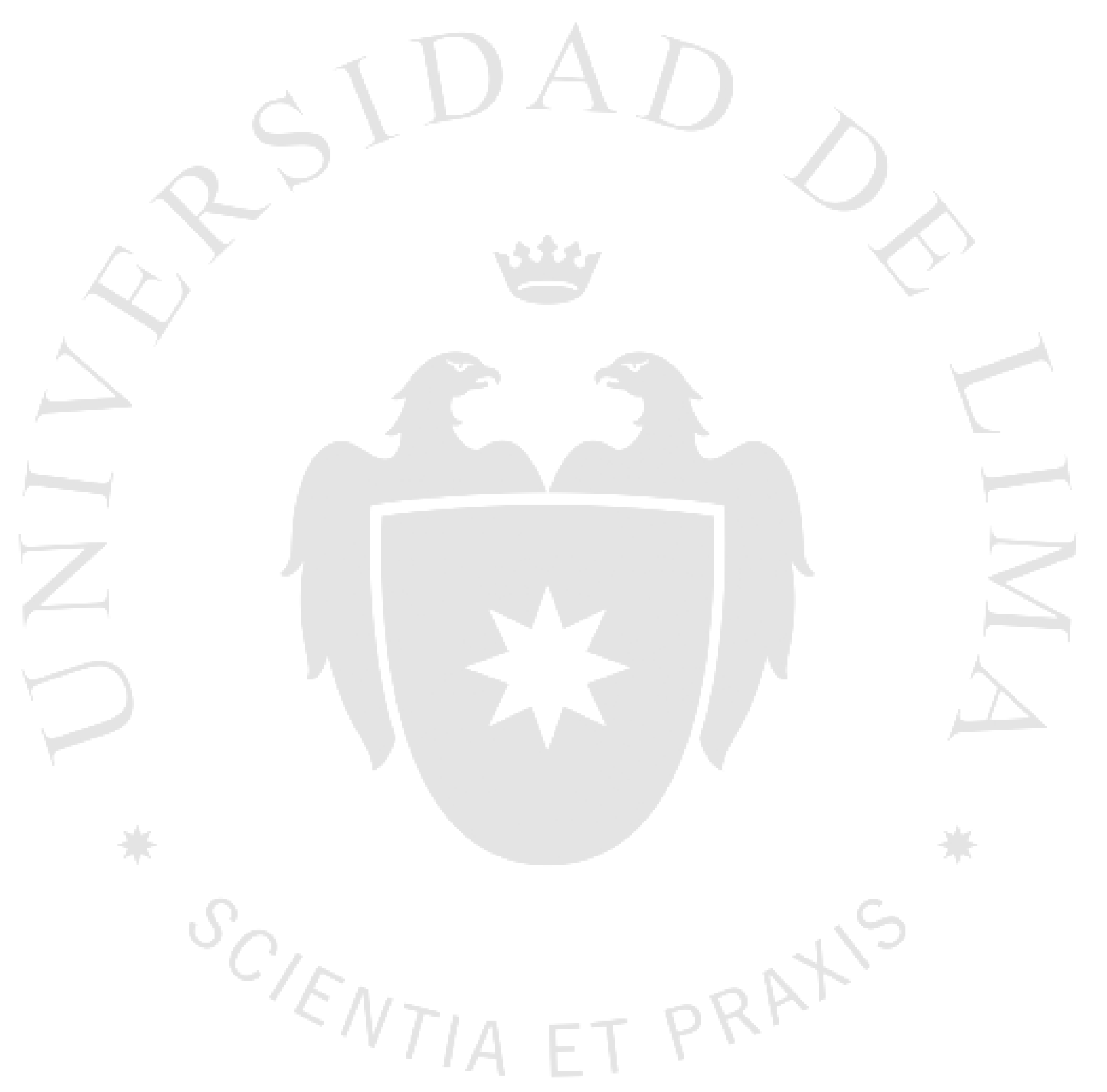


4.1.- La herencia de la mujer vengativa: Kaibyo eiga en el cine de Park Chan-wook.

El cine fantástico japonés cuenta con una larga tradición que se remonta al período entre los años cincuenta hasta finales de los años sesenta, tiempo en que se producen un gran número de cintas que tratan el tema de los espectros y gatos: el Kaibyo eiga. Estas películas son un subgénero del Kaidan eiga clásico, películas que tratan de fantasmas y espíritus realizadas en Japón. Como escribe Rafael Malpartida:

El surtidor argumental de estos filmes, que giran en torno al mundo samurái, se remonta, naturalmente, a añejas leyendas de transmisión oral, y el primer hito que fija literalmente su impronta se encuentra, como es habitual para el mundo fantasmal en Japón, en el teatro kabuki: Hana no Saga nekomata soshi (1853), de Segawa Joko III (Malpartida 2014: 38).

En el subgénero de Kaibyo eiga, como señala Malpartida (2014): 
Las tramas son recurrentes y giran en torno a la injusticia que comete el poderoso, asesinando o llevando al suicidio a una o varias personas, que en asociación espectral con un gato vuelven del Más Allá para vengarse (Malpartida 2014: 34).

Estos espectros que vuelven de la muerte casi siempre lo hacen en la figura de la mujer que muere a causa de los abusos de los samuráis, en cuyas agonías siempre aparece un gato, comúnmente llamado Tama, que bebe su sangre y da inicio al retorno del espíritu atormentando para cobrar venganza. Las películas más representativas de este periodo son las que cierran el ciclo, asentadas en las sólidas bases con que ya contaba el subgénero; son Kuroneko (K. Shindo, 1968) y The haunted castle (Hiroku kaibyo-den, T. Tanaka, 1969).

En la obra de Park Chan-wook en que se explora la temática de la mujer vengativa se toma algunos elementos del Kaibyo eiga, que resaltan al estar acompañadas del toque sutil del autor. Tanto Lady Vengeance, Stoker como The handmaiden son películas donde el director da el protagonismo a la venganza que llevan a cabo mujeres contra los hombres que les hicieron algún mal, al igual que las cintas de fantasmas gato. Sin embargo, Park rompe el nexo de la venganza con el mundo espectral para insertarlo en lo cotidiano, donde son los límites de la realidad los que ponen la pauta para lo horrendo. Si bien sus protagonistas no regresan del inframundo ni necesitan un nexo como la figura del gato para ello, sin embargo salen de las circunstancias trágicas donde han sido colocadas para cobrar venganza, elaborando de esa manera su propio retorno.

En la primera escena de Lady Vengeance se muestra a un predicador esperando ansioso en el frío la salida de Geum-ja tras cumplir su injusta condena de trece años en prisión por el asesinato del niño Park Won-mo. Junto con una banda de chicas que tocan una canción sobre la superación de obstáculos reciben a la joven que lo ayudó como guía espiritual en prisión, y a la cual considera casi como un ángel, y le entrega un pastel de tofu como signo de purificación. Geum-ja reacciona tirando el pastel sin darle importancia y con voz parca le pregunta: "¿Por qué no te vas a la mierda?". Con estas imágenes se ve el regreso de Geum-ja al mundo libre, donde puede poner a practica su plan para cobrar venganza del hombre que le hizo el mal, al igual que las mujeres espectrales del Kaibyo eiga. 
Otra característica de las mujeres del cine de fantasmas gato es la transformación del cuerpo. Cuando regresan de la muerte como espectros, lo hacen con rasgos de gato, recurriendo a los mínimos recursos de maquillaje para no caer en lo hilarante: cejas y boca alargadas, colmillos agrandados, pelo alborotado con pequeñas orejas y ojos brillantes. Aparte de los cambios en el cuerpo, también la transformación afecta el comportamiento y los gustos asemejándolos con el animal que las trae del Más Allá. Utilizan sus encantos para seducir a los samuráis, aislarlos y asesinarlos. Hipnotizan a sus víctimas por medio de una danza que simula los movimientos del gato: la curiosa posición de las manos a modo de zarpas durante el baile, en las cuales parecen representar la voluntad de la víctima. Malpartida describe una escena de The ghost cat of Ouma Crossing (Kaibyo Omagatsuji, Bin Kado, 1954), donde se ejemplifica esta habilidad de manejar a las personas como títeres, "Este sádico ritual otorga al monstruo un inquietante componente de crueldad, pues podía haberse lanzado al cuello de la joven sin necesidad de marearla una y otra vez" (Malpartida 2014: 47).

La transformación que se da en los personajes femeninos de Park Chan-wook no pasa por cambios evidentes en lo físico, debido a que toma distancia de lo sobrenatural. El cambio va por el comportamiento y el uso de la seducción como herramientas para lograr sus objetivos. Lady Hideko en The Handmaiden utiliza el poder de sus encantos para aislar y dejar inconsciente al Conde Fujiwara, lo que tendrá como consecuencia su tortuosa muerte en manos del pervertido Tío Kouzuki. El cambio de comportamiento de India Stoker, muestra una confianza que seduce y convence al tío Charlie para confiar en ella, aunque momentos después le vuele los sesos con la escopeta con la que iba a cazar con su padre, quien fuera asesinado por ese mismo tío.

Por último, tenemos el tema del aislamiento de la mujer vengativa. En el cine de mujeres espectro la venganza requiere un tránsito solitario rodeado de misterio y cumple un doble rol. En primer lugar, evidencia su propio aislamiento para esconder su faceta monstruosa y no poner en riesgo su venganza. Es el caso de la mujer espectro Sawanoi (en The Haunted Castle), que, al ser sorprendida por una criada mientras se lame las manos con su enorme lengua, tan roja que parece que brota sangre de ella, pone al descubierto su monstruosidad. Presenciar este acto es fatal para la criada, quién inmediatamente muere a manos del espectro. En muchas de las películas del Kaibyo eiga, las criadas, en su mayoría, son asesinadas por atestiguar las caracterizaciones 
monstruosas de las mujeres gato, y por poner así en riesgo sus planes. En segundo lugar, está el tema de la soledad, que contribuye a poner fin a la vida de los samuráis, seduciéndolos con sus encantos para darles muerte por medio de una mordida en el cuello (una muerte común para estos personajes en las cintas del subgénero). Es también el caso de la primera víctima de los fantasmas gato que muestra el realizador Kaneto Shindo en su filme Kuroneko. un soberbio samurái que bebe sake junto a los dos espectros -madre y esposa de Hachi, muertas por el abuso de dos samuráis- que lo adulan para que demuestre su vileza. Ya ebrio, el tipejo se le insinúa al espectro más joven, quien lo conduce hasta el tatami donde hace uso de sus colmillos para quitarle la vida.

Al igual que los espectros del Kaibyo eiga, las mujeres vengativas del cine de Park Chan-wook esconden sus intenciones fatales bajo una faceta de inocencia e ingenuidad. En el caso de Lady Vengeance, Geum-ja pasa los trece años de su condena mostrándose como una persona noble y arrepentida, siempre dispuesta a ayudar a las demás reclusas. Con ello esconde su elaborado plan de venganza contra Mr. Baek, a quien finalmente aísla para darle muerte junto a los padres de los niños que asesinó. Las falsas apariencia y el engaño son parte importante en The handmaiden, donde Lady Hideko y Sook-hee se esconden tras la apariencia de mujeres vulnerables que demuestran ante el Tío Kouzuki y Conde Fujiwara, y luego aprovechan esas circunstancias para elaborar un plan de escape para vivir su amor y aislar a esos hombres para que se maten entre sí.

\section{2.- Del J-horror}

El cine de horror asiático se ha caracterizado por la relevancia que da a lo trágico en sus historias. Tragedias compuestas por los traumas del pasado, la venganza, la desolación, el aislamiento, las apariciones de seres fantásticos, y sobre todo, el misterio que rodea las historias. La obra de Park Chan-wook no es ajena a esas características, pero el uso que les da no consiste en replicar la misma figura; él utiliza los temas, pero les da su propio matiz. En su caso, la predilección por la venganza es inobjetable. Dicha temática hace que sus películas se caractericen por una brutalidad intensa que se esfuerza en demostrar tanto en la imagen como el tratamiento del sonido, técnicas muy personales que se explayan en lo explícito (tomadas de las J-horror) para ayudarse a demostrar lo visceral de los actos de sus personajes al dejarse llevar por la perdición de la venganza. 
El sonido, ya que estamos en el tema, es un recurso técnico que se maneja con suma sutileza en el cine de Park Chan-wook. No se usa solo como un complemento para la muestra del horror en lo visual: también ayuda a introducir la atmósfera adecuada para la creación del suspense. En la escena que precede al clímax de Lady Vengeance, donde Geum-ja congrega junto al detective Choi a todos los familiares de los niños asesinados por Mr. Baek en una escuela abandonada, Giem-ja muestra a los padres, por medio de unas cintas de video que guardaba el asesino, las sórdidas circunstancias que sufrieron sus niños antes de morir.

Park utiliza la edición de la imagen y el sonido para demostrar el sufrimiento de los niños representados por los gestos de indignación de los padres. El llanto de las víctimas, proveniente de la televisión donde se están reproduciendo los videos, domina el ambiente y solo muestra los rostros de los padres horrorizados por lo que están viendo. El silencio de los padres se rompe con el ruido que produce la caída de una anciana desde su silla por la impresión al ver la muerte de su nieta. El ruido del tambaleo de la silla acentúa el horror lo que se está viendo: Mr. Baek tiene a la pequeña parada sobre una silla con una bolsa negra en la cabeza y una soga alrededor del cuello. El asesino retrocede unos pasos y jala sin ninguna muestra de compasión la silla que está a los pies de la niña. Luego el llanto de los padres se va equiparando al de sus niños, mostrando ese dolor que va renaciendo junto con la ofuscación y la tristeza. Al finalizar de la escena, la cámara panea dejando fuera de cuadro a los desesperados padres para llegar a Geum-ja, parada aún al lado del televisor, con las manos en las orejas, evitando escuchar el dolor que a ella tanto la atormenta.

En la escena el uso de sonido y la imagen se conjugan para mostrar el horror que sufren los padres sin caer en la explicitud de la sangre, evidenciando un manejo sutil en el uso de los recursos. Park mueve la sensibilidad del espectador al utilizar el sonido diegético de las grabaciones de Mr. Baek; la naturalidad de ese sonido sucio y la mala calidad características de las cintas de video logran que el espectador tenga la sensación de estar contemplando algo verídico. Esto produce sensaciones viscerales, y logran el mismo efecto que logra el recurso sonoro de magnificar lo explícito en las J-horror. La escena provoca el mismo sobresalto en el espectador que muestran las secuencias truculentas del horror japonés, pero con un componente adicional, que se debe a la 
capacidad magistral del realizador: el efecto impactante se mantiene en escena por más de diez minutos sin derramar una gota de sangre.

Lo que viene a continuación es la discusión de los familiares de los niños con Geum-ja y el detective Choi. Ellos les dan la posibilidad de castigar por mano propia al asesino de los pequeños o entregarlo a las autoridades. Descartan la posibilidad de entregarlo a la ley para encontrar justicia y la conversación se vuelca en una intensa discusión sobre cómo deben cobrar venganza del asesino sin correr el riesgo que alguien del grupo los delate como asesinos. Geum-ja recurre a su experiencia como asesina para despejar las dudas por si alguien hablara, intimidándolos con suaves palabras sobre su pericia en la venganza. Sin tener que preocuparse más por eso, planean cómo asesinarán a Mr. Baek, si será en grupo todos juntos o individualmente. Uno de los padres, con la frialdad característica de un hombre de negocios, dice: "Cada uno por su cuenta, a la carta; no todos tenemos por qué comer el mismo menú“. Momentos después, la cámara panea hacia un micrófono que está en la misma habitación a un lado. En el momento no se entiende su función ahí; luego, se muestra el trayecto de la conexión que sale del micrófono por medio de un travelling que llega hasta un parlante en la habitación donde Mr. Baek está amordazado y sujeto a una silla con un gran plástico a sus pies, preparado para la matanza. Él escucha todo sobre cómo van planeando su muerte, y tiene un horrendo adelanto de su trágico final.

Si bien la discusión que sostienen sobre la muerte de Mr. Baek de por sí es truculenta, Park nos hace ver que no es suficiente; la magnifica al mostrar que el asesino es testigo de la venganza que caerá sobre él. La sorpresa de este hecho es lo que intensifica el efecto de horror que logra en la escena. El clímax llega con la imagen de los padres sentados en una banca, uno al lado de otro, pasándose cobertores de plástico transparente para no manchar sus ropas y todo tipo de armas filosas para llevar a cabo su plan. El silencio se mantiene por unos segundos creando el suspense, algunos susurros lo interrumpen por momentos hasta escuchar el sonido de una cortina que se abre, indicando que el momento ha llegado. La madre de Won-mo se pone de pie, dejando escuchar el sonido incómodo del plástico que la cubre su cuerpo mientras se estira. La sensación que produce el sonido describe la situación. 
A final, el proceso de la tortuosa muerte de Mr. Baek solo la componen los sonidos, la imagen solo muestra el sufrimiento de los padres luego de efectuar su venganza. Lo explícito en lo visual llega cuando Mr. Baek está muerto. El encuadre se posa sobre la cabeza inerte del asesino mientras el detective Choi saca de su cuello las tijeras marcadas con el nombre de una de sus víctimas, que fueron las que le produjeron la muerte. El movimiento lento en la acción y el plano de detalle que se utiliza muestran el horror en lo visual. Park Chan-wook decide mostrar el post del acto, la limpieza de la escena del crimen entre todos los involucrados; es ahí donde la sangre gana protagonismo en planos quietos y apacibles que nos deja contemplar. Los detalles de la sangre cayendo a un balde de metal demuestran lo brutal de la acción. A la vez, en ángulo cenital, se ve el trabajo organizado de los familiares junto con Geum-ja y el detective Choi, para no dejar huella del crimen. Con la música que acompaña las acciones, Park compone la escena como un ritual de la venganza consumada. 


\section{CAPÍTULO V \\ LA VENGANZA EN LOS GÉNEROS}

\section{1.- El uso de los géneros en el cine de Park Chan-wook}

El cine de Par Chan-wook se nutre, por lo general, de la venganza que llevan a cabo sus personajes, exponiéndolos a un sinfín de circunstancias que pasan a ser desde sospechosas e intrigantes hasta cómicas, pasando por algún sentido retorcido, hasta llegar a lo hilarante. Las características de esas circunstancias son elementos claves de algunos géneros que encontramos frecuentemente en el cine de este realizador. Muestra una preferencia por la intriga y la sospecha nos lleva siempre al género del thriller y el policial; y. para alivianar las cargas emocionales intensas que genera en el público, da un respiro con cargas significativas de comedia y melodrama (este último, su género predilecto para vestir el escenario). Las pinceladas finales, como todo buen artista, las decora con elementos del terror y del cine de horror, mostrando mediante esos recursos los rasgos más viles, brutales e intensos que van adquiriendo sus personajes cuando recorren el camino de la vendetta. Estas particularidades podrían ser interpretadas como muestras de un exhibicionismo absurdo, pero son más bien detalles esenciales para que el público infiera la composición total de sus personajes, en un sentido que va más allá del mero efectismo. Park se ayuda de la versatilidad de los géneros para introducirnos en la esencia de sus personajes, cualidades que sería difícil mostrar sin la versatilidad que caracteriza a los géneros, una peculiaridad que Altman (2000) analiza así: 
En los cómics siempre aparecen extraños artefactos capaces de desempeñar las más diversas tareas. Algo parecido sucede con la visión que normalmente se tiene del género. Con una versatilidad poco menos que mágica, los géneros resisten dentro de la teoría cinematográfica gracias a su capacidad de desempeñar múltiples operaciones simultáneamente. Según la mayoría de los críticos, los géneros aportan las fórmulas que rigen a la producción; los géneros constituyen las estructuras que definen a cada uno de los textos; las decisiones de programación parten, ante todo, de criterios de género; la interpretación de las películas de género depende directamente de las expectativas del público respecto al género. El término género abarca, por sí solo, todos esos aspectos (Altman 2000: 39).

\subsection{2.- El thriller}

Si esta cualidad versátil con la que cuentan los géneros ayudan a la identificación de sus personajes, entonces la temática de la venganza debe ser la causante de las preferencias del director por el thriller y el policial. La venganza en el cine de Park requiere intriga; los personajes no pueden llevarla a cabo sin generar esta sensación en el público, cualidad que es perfecta para ser mostrada en el escenario del thriller, sobre todo en el dinamismo vertiginoso de sensaciones y emociones que muestra el director en todas sus películas. Esta intensidad en la muestra de emociones en los films de Park obedece a la búsqueda que demandan los thrillers según Martin Rubens:

Lo importante para el concepto de thriller es no solo un exceso de sentimientos, sino el asunto de cuáles son los sentimientos que son acentuados. El thriller busca despertar miedo, suspense, excitación, vértigo y movimiento. En otros términos, enfatiza lo visceral, lo primario, en vez de aspectos más sensibles o cerebrales como la tragedia, la aflicción, la compasión, el amor o la nostalgia (Rubens 2000: 14).

Como señala el mismo Rubens: "El thriller busca sensaciones, más que sensibilidad: es un medio para crear sensaciones" (2000: 14). Las emociones que tienen los personajes de Park en su búsqueda de venganza obedecen a las demandas del director 
por crear sensaciones idóneas para introducir a los espectadores en cada una de sus historias. Por eso el thriller es parte fundamental del cine de Park Chan-wook; este género que se mueve dentro de otros géneros le brinda la plataforma adecuada para la creación de atmósferas y sensaciones en su tratamiento de la venganza. Esta movilidad que muestra el thriller, que se puede apreciar claramente en la cinematografía de nuestro autor, entre otros géneros, Rubens lo retrata así:

El concepto de thriller se encuentra en algún lugar indefinido entre un género genuino y una calidad descriptiva que se atribuye a otros géneros más claramente definidos, como pueden ser los thrillers de espías, los thrillers de detectives o los thrillers de terror. Probablemente no exista un auténtico y puro "thriller de thriller". El thriller suele ser conceptualizado como un "metagénero", que engloba a otros géneros bajo su manto, y como una banda en el espectro que colorea a cada de uno de esos géneros particulares (Rubens 2000: 16).

\subsection{3.- El policial}

La hibridación de géneros característica del cine surcoreano, que ha ayudado a darle una identidad a su cinematografía, no escapa a los alcances de Park Chan-wook. Tanto como el thriller que ocupa el lugar de metagénero en toda su filmografía, el policial ocupa también parte importante en su tratamiento y narrativa. Este es un género en el que prima la ocultación de hechos, desviando la atención y generando múltiples sospechas: nada es lo que parece. En Lady Vengeance, la canica de Won-mo es un dato transcendental en la historia: no solo indica quién es el verdadero culpable, sino que, al saberse su significado, amplia el alcance del mal del Sr. Baek, cuando la vemos pendiente de su celular junto a otros objetos que guardaba de sus pequeñas víctimas. Este dato oculto, cuando se revela, desembocará en un extraordinario desenlace. De igual forma, los zapatos de taco de India Stoker (Mia Wasikowska) en la escena inicial, que se verá después que representan su transición a un cambio maligno y son la representación de la pérdida de su inocencia.

Otra característica del policial que traslada a sus historias es la existencia de un crimen inicial sobre el cual giran las historias. En Stoker, la trama se mueve en torno a la repentina muerte del padre de India Stoker, y la inmediata aparición del su tío Charlie 
(Matthew Goode), del cual nunca se ha sabido hasta el día del entierro. Desde ese momento se entra al sutil juego de descubrir quiénes son estas personas por medio de las miradas de cada personaje; las sospechas generan una atmósfera de tensión y suspense propios del policial. En Lady Vengeance también se comienza con el asesinato del inocente Won-mo en las supuestas manos de Geum-ja. Después se sabe que ella no es la culpable, sino que ha sido víctima de un chantaje por parte de Mr. Baek. Los trece años que ella pasa en prisión, por un crimen que no cometió, los pasa planeando una minuciosa venganza contra él.

\subsection{4.- La comedia}

El humor es otro elemento común en las cintas de Park Chan-wook, ya que, al tratar la venganza con tanta intensidad emocional, tiene que rebajarla con un toque de ironía. Es a través de lo irónico que entra la comedia a sus filmes, ironías que resultan ser sarcasmos extravagantes que saltan al campo del humor negro. En la primera secuencia de Oldboy (2013), muestra a Oh Dae-su detenido en la comisaría, aparentemente arrestado por generar algún disturbio y en evidente estado de ebriedad. Por medio de jump cuts nos muestra sus acciones revoltosas que la policía trata de controlar, retratando a este hombre adulto con el comportamiento de un niño malcriado cuya rabieta se va intensificando; llega hasta el ridículo cuando es esposado a la pared luego de haberse tirado al piso a modo de pataleta, protestando para que lo dejen salir y pueda ir al cumpleaños de su hija. Finalmente, un amigo acude a sacarlo; Oh Dae-su está parado a su lado más tranquilo, con la camisa anudada a la altura del ombligo. Su amigo se disculpa por el comportamiento de su compañero alegando que en realidad es una buena persona; justo en ese instante, Oh Dae-su insulta a los policías y sale corriendo, dejando a su amigo solo con una sonrisa nerviosa e inmediatamente sale detrás de él. Así termina la escena con la ironía del comportamiento de un niño en un hombre adulto.

Otro momento donde se vale de la ironía para aligerar la intensidad de la acción es antes y después de la extraordinaria escena en que Oh Dae-su pelea por el pasadizo contra todos los gansters que trabajan para Cheol-ung, su ex carcelero. Antes de enfrentarse a ellos, tiene sujeto a Cheol-ung del cuello con un trapo totalmente ensangrentado en la boca, a causa de la hemorragia que le ha provocado Dae-su al quitarle todos los dientes con el sacaclavos de un martillo. Antes de iniciar, pregunta a todos quién 
tiene sangre AB. Dos levantan la mano extrañados y le dice que lo lleven al hospital porque "ha perdido mucha sangre“. Luego, después del enfrentamiento donde vence a todos los secuaces ayudado de un martillo y sus puños, termina muy golpeado y con un cuchillo incrustado en la espalda. Parado al final del pasadizo, se escucha el timbre que anuncia la llegada del ascensor. Se ve que el rostro de Dae-su cambia de un gesto cansado al de una ligera sonrisa, al ver que en el ascensor que acaba de llegar hay más sujetos que vienen por él. Se pasa a un corte que inicia con el mismo timbre del ascensor, se abren las puertas y caen los sujetos inconscientes por la golpiza que les ha propinado Dae-su, quien sale caminando casi moribundo.

También muestra este humor negro en las otras películas de la trilogía. Cuando Ryu, en Symphaty for Mr. Vengeance, está orinando en un baño público y los traficantes de órganos vuelven a pegar sus anuncios. Minutos antes, el encargado de la limpieza del baño sacaba con mucho esfuerzo los mismos anuncios. Lo mismo ocurre en la secuencia en que Ryu, discapacitado por su sordomudez, va a enterrar a su hermana en el río donde solían jugar de niños, y es interrumpido por otro discapacitado (con un retardo psicomotor) y, entre ambos, no pueden evitar la muerte de la pequeña niña secuestrada. El humor llega en esa escena a burlarse de las dificultades que muestran los dos discapacitados para comunicarse, para terminar en una consecuencia trágica. En Lady Vengeance se ve el humor negro en la condena de la protagonista, que entra siendo inocente a la cárcel y sale de ella siendo una asesina. La institución solo empeoró las cosas. Asimismo, se muestra personajes grotescos, como la lesbiana caníbal llamada "La Bruja", de quien hereda el apodo al matarla por envenenamiento.

\subsection{5.- El melodrama}

Sin duda, un género que no puede faltar en el cine de Park es el melodrama. Tampoco en el cine surcoreano, en donde el género se puede considerar como el más dominante, según lo señala Julian Stringer: (2005: 97): “One overarching perception is that a specific genre does - or should- hold pride of place above all others in South Korea, namely melodrama". Lo que resalta en él es su forma de narrar la puesta en marcha de la venganza, "basada en sus giros súbitos de la acción, el juego simplificado de sus connotaciones morales, y el resorte sentimental y apasionado con que mueve a sus personajes" (Reyes, Ribeiro, Bravo y Bettini, 2010, p. 40). Centra la temática en los 
conflictos emocionales de los personajes y entre ellos. En su última producción, The handmaiden (2016), película ambientada en la Corea de los años treinta durante la colonización japonesa, se narra el encuentro amoroso entre dos mujeres en un curioso juego sobre las falsas apariencias. Sook-hee (Kim Tae-ri) es contratada como doncella personal de Hideko, una acaudalada mujer japonesa que vive recluida en su gran mansión a cargo de su retorcido tío, que planea convertirla en su esposa. Un estafador envía a Sook-hee, una ladronzuela, a trabajar en la mansión de Hideko para que la persuada a que se enamore de él bajo el nombre de un conde japonés. Una vez que Hideko se enamore del supuesto conde, el estafador junto con Sook-hee tienen un plan para quedarse con su fortuna.

La película se cuenta en dos partes; una, desde la perspectiva de Sook-hee y su plan con el estafador; y la otra, desde el lado de Hideko con el mismo estafador. La historia se une cuando ambas mujeres caen en la cuenta de que están enamoradas y que han sido utilizadas por el yugo de la masculinidad, representada en la tiranía del estafador y el tío. El juego de connotaciones morales es sobrepasado por la pasión de ambas mujeres, que se rebelan y se vengan de la dominancia masculina por medio de su sexualidad. La venganza siempre se muestra como el punto medular en el cine del autor, cuya temática requiere de giros inesperados en la acción y sirve como base que soporta una gran cantidad de géneros. En el caso de The handmaiden, el melodrama se basa en la historia de amor de estas dos mujeres, que han vivido sometidas por el asedio masculino. Hideko ha vivido esta opresión y abuso desde muy pequeña, educada para ser narradora de las historias pornográficas de la extensa colección de libros retorcidos de su tío. Antes de ella, la esposa de su tío cumplía esta función, y termina colgándose de la rama de un árbol de durazno frente a la mansión. En ese mismo árbol Hideko años después intentaría acabar con su vida, para ser salvada por Sook-hee. Con este evento ambas caen en cuenta del verdadero amor que sienten la una por la otra.

\subsection{6.- El terror}

Otro género que incluye Park Chan-wook en esta hibridación que realiza en sus películas es el terror, aunque más orientado hacia el subgénero del horror. Destacando siempre las características del terror para obtener el completo asombro del espectador, "su trama - con o sin elementos fantásticos- va dirigida a producir en el espectador 
emociones como miedo, temor o pánico y jugar con estas emociones al someterlo a suspensos, sobresaltos y ansiedades" (Atom, 2005, párr. 13). En sus películas sobre la venganza, estos elementos forman parte esencial de la narración para acentuar la determinación de los personajes a llevarla a cabo. Así, tenemos, por ejemplo, la secuencia de la tortura a Cheol-ung por Oh Dae-su en Oldboy, en donde, por medio de planos de detalle y primeros planos, se observa la extracción de los dientes de Cheol-ung con el sacaclavos del martillo. Puede verse la sangre que brota por la brutal extracción, el rostro decidido de Dae-su al realizar el acto, y los dientes con las raíces aún encarnadas cayendo en el teclado de la computadora.

También se encuentran estos elementos, que generan sobresaltos y ansiedad en el espectador, en la secuencia en que Woo-jin le da vuelta a la venganza de Dae-su, explicándole que todos sus años de encierro eran parte de su plan para vengar el suicidio de su hermana, quien acabó con su vida por las habladurías producidas por Dae-su cuando aún era un escolar. También le revela que Miko, la joven con la cual están mutuamente enamorados, es en realidad su hija, y que le hará conocer a la chica la verdad sobre su padre poniendo en evidencia el incesto. Oh Dae-su le ruega que no lo haga y se cercena la lengua en pago por las penas que pasó Woo-jin todos estos años. El momento en el que coge unas tijeras para cortarse la lengua está dotada del suspense propio del terror, y genera ansiedad por el acto que va a realizar el Dae-su. La escena no es tan gráfica como la de la tortura que le propina a Cheol-ung con el uso de un lenguaje de planos de detalle, pero crea el ambiente sonoro para mostrar la misma explicitud al escuchar cómo el metal filoso cercena la lengua de su protagonista. 


\section{CAPÍTULO VI \\ LA VENGANZA COMO AGENCIA}

\section{1.- Estructura y agencia en el cine de Park Chan-wook}

Dentro de la teoría estructuralista el sociólogo Anthony Giddens se trabaja bajo dos conceptos para entender las capacidades del individuo y los roles que juegan dentro de la sociedad. Ambos conceptos son los de estructura y agencia, importantes para entender cómo funcionan los cambios sociales a partir del empuje del individuo. Giddens los define así:

Dicotomía conceptual basada en los intentos de la sociología para entender el equilibrio relativo entre influencia de la sociedad sobre el individuo (estructura) y la libertad del individuo para actuar y dar forma a la sociedad (agencia) (Giddens y Sutton 2015: 59).

Se entiende así que la estructura es el mundo que rodea al agente, lo cual prioriza el papel del agente por su capacidad de acción para lograr con ello el cambio dentro de las circunstancias que le impone la sociedad. Para Giddens, agencia y estructura dependen uno del otro, se influencian constantemente en un proceso cíclico que los ata a una dependencia mutua. Sobre ello dice lo siguiente:

La estructura y la agencia se implican mutuamente. La estructura permite, no solo restringe, y hace que la acción creativa sea posible, pero las acciones repetidas de 
muchos individuos contribuyen a reproducir y cambiar la estructura social (Giddens y Sutton 2015: 59).

Para entender mejor los límites de los conceptos de estructura-agencia, Giddens marca una brecha diferenciadora de sus conceptos entre lo macro/micro en el ámbito de los estudios sociales, importante para percibir cuáles son los límites de acción de la agencia:

Podría creerse que los estudian las estructuras sociales se centrarán en los fenómenos a gran escala en el nivel macro, haciendo caso omiso de la acción individual, mientras que el estudio de la agencia se fijará solo en las acciones individuales en el nivel micro. No es una mala regla general, pero en el nivel micro hay interacciones estructuradas y relaciones que implican estudiar las acciones individuales y, a la inversa, es posible sostener que no solo los individuos "actúan", sino también los entes colectivos, como los sindicatos, los movimientos sociales y las empresas y por lo tanto son una agencia creativa en formación de la vida social. De esta forma la dicotomía estructura/agencia no se corresponde del todo con la distinción macro/micro (Giddens 1995: 63).

Lo importante de la distinción que nos da Giddens es que las acciones individuales dentro de la agencia no necesariamente parten de actos individuales, sino que pueden ser actores que forman colectivos que actúan para lograr un cambio común en la sociedad en la que habitan, en la estructura social que se rige por un orden y organización entre las diversas esferas sociales.

En el cine de Park Chan-wook, la agencia se manifiesta en la capacidad de acción que tienen sus protagonistas femeninos para buscar un cambio de sus situaciones en la sociedad que las oprime: la venganza es lo que guía sus actos. Sin embargo, antes de entrar al detalle en su tránsito por la vendetta, es importante explicar cómo perciben los individuos sus acciones y cuáles son las consecuencias inadvertidas y no buscadas con las que se encuentran. Esto se explica mediante el modelo estratificado del agente, que Giddens representa de esta manera: 


\section{Modelo estratificado del Agente}

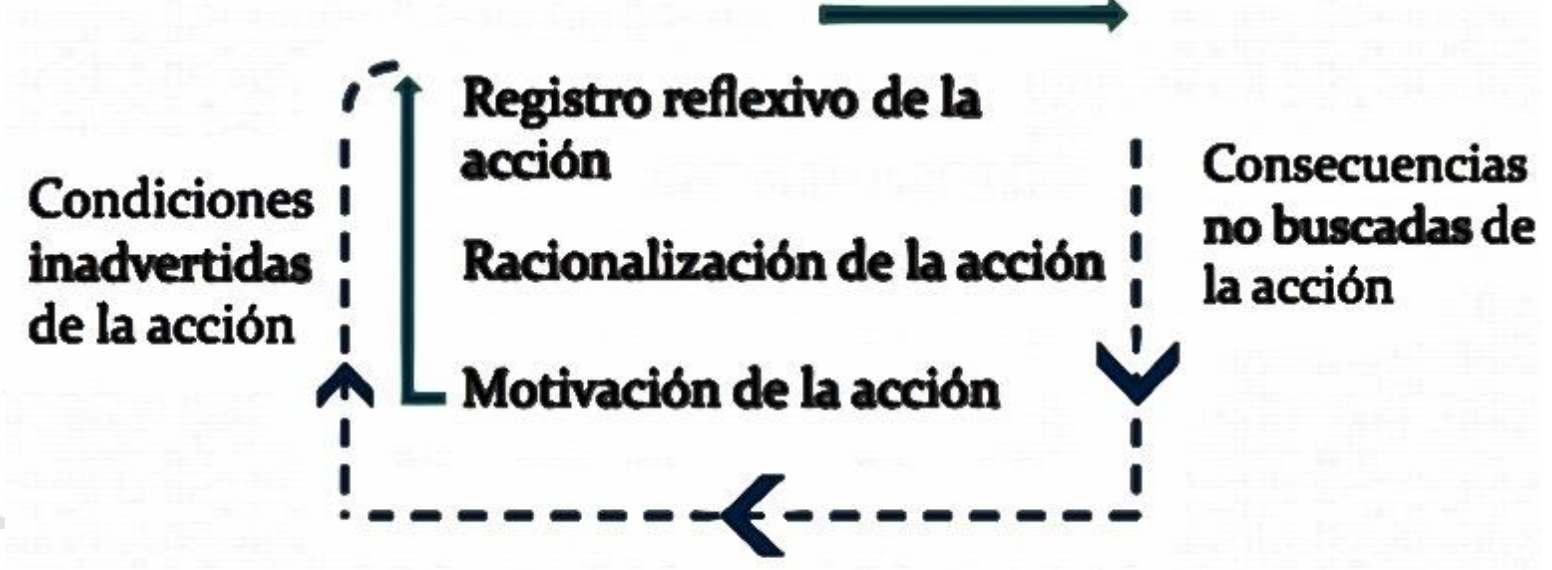

El modelo que propone Giddens consiste en analizar la autovigilancia (registro reflexivo), la racionalización y la motivación de la acción del yo actuante (agente). Estos procesos no tienen una relación consecuente, ninguno precede al otro, sino que se dan como un conjunto de procesos insertos unos en otros. Giddens explica los procesos de su modelo así:

- Monitoreo reflexivo de la acción: característica crónica de la acción cotidiana, que incluye no solo la conducta del individuo sino la de los demás. Es decir, los actores no solo vigilan continuamente el flujo de sus actividades y esperan que otros hagan lo mismo que las suyas, sino que también vigilan de manera rutinaria aspectos físicos y sociales de los contextos en los que se mueve.

- Racionalización de la acción: da por entendido que los actores, de manera rutinaria y sin titubear, mantienen una continua "comprensión teórica" de las bases de su actividad. En general se espera que los actores sean capaces de explicar lo que hacen si se les pregunta. Solo de manera excepcional se preguntan las razones o las intenciones de la conducta.

- Motivación de la acción: Distinto a los procesos de reflexión y racionalización por no pertenecer al ámbito de la acción. Las motivaciones se refieren a los deseos que se suscitan. Muchos de los motivos proporcionan 
planes o programas dentro de los cuales se establece un rango de conductas. Una gran parte de nuestra conducta diaria no está motivada directamente Giddens (1995).

En estos procesos el agente encontrará consecuencias no buscadas o inadvertidas en sus actos, pero que serán importantes para su propia reflexividad y el continuo cambio de la estructura.

\subsection{2.- La agencia de Lady Hideko y Sook-Hee: la sexualidad como} herramienta de venganza contra la dominancia masculina

The Handmaiden es la última producción de Park Chan-wook, recreada en la Corea de los años treinta, momento en que el país fue colonia japonesa. La cinta está basada en la novela Falsa identidad de Sarah Waters, cuya trama ambientada en la época victoriana; Park Chan-wook respeta la división de la trama en tres partes y esta gira en torno a cuatro personajes. La primera parte nos muestra la llegada de Sook-hee (Kim Taeri) a la mansión de Lady Hideko (Kim Min-hee), para servirle como su criada personal, enviada por un estafador (Ha Jung-woo), que planea enamorarla para despojarla de su fortuna. El estafador se hará pasar por un aristócrata japonés llamado Conde Fujiwara, quien llega a la mansión como el maestro de pintura de Lady Hideko y como falsificador de novelas para el malvado tío Kouzuki (Jo Jim-woong), quien crió a Hideko para ser la narradora de los eróticos y pervertidos pergaminos de su biblioteca, lugar donde esconde su trastornada personalidad. El estafador confabula con Sook-hee para que persuada a su ama para que se enamore de él, ofreciéndole parte del botín que obtenga una vez logrado su plan. La historia empieza siguiendo esa línea, pero toma giros inesperados en los que el engaño y las falsas apariencias entre los personajes llevan a un final en que la venganza es el camino a la liberación de estas dos mujeres.

La primera parte del film se muestra desde la perspectiva de Sook-he, quien entra a la casa como cómplice para aprovecharse de la inocente de Lady Hideko, y es en esta primera línea de la historia donde se muestra el origen de las motivaciones para actuar de estos personajes. Tanto Sook-he como Lady Hideko tienen otra intención la una con la otra, ambas creen que una le está sirviendo a la otra para cumplir finalidad que buscan: Sook-he actúa como su doncella para quedarse con parte de la riqueza de Hideko; 
y la aristócrata tiene el plan de usar a Sook-hee para poder librarse de las oscuras intenciones de su enfermo tío. Sin embargo, ambas se enamoran en este juego de engaños. La escena de la tina, cuando la doncella lima con ternura el diente de la ama, es el inicio de la seducción y lo que dará pie a la liberación de su sexualidad. Esta se muestra con un juego de primeros planos entre las miradas de ambos personajes que sugieren el deseo naciente.

La relación entre ama y sirvienta se va intensificando, y crea situaciones de celos y envidias entre ambas. Es el caso de la escena en que Hideko le cuenta a Sook-hee que aceptó la propuesta de matrimonio del Conde Fujiwara, en la cual los sentimientos entre ama y criada no se pueden disimular. Sook-hee, oculta sus sentimientos y finge alegría con la noticia, lo cual motiva la ira de Hideko, que la echa de su habitación con desprecio. Así nace una relación del secreto y los deseos que van suscitándose en esta primera parte de la historia. El amor que sienten la una por la otra es lo que será su motivación para actuar. La motivación parte del inconsciente, como señala Giddens, y este suceso es el punto de partida en la construcción del destino que se hacen ambas protagonistas.

La segunda parte de la historia se cuenta desde la perspectiva de Lady Hideko, y se muestra su confabulación con el estafador y sus planes de utilizar a Sook-hee para someterla a un destino frustrante. Hideko ya no es la ingenua e inofensiva mujer de la primera parte; ahora su conducta es fría y egoísta, pues se conoce su plan para liberarse del destino que le depara su tío Kouzuki, quien desde niña la ha criado para que sea la narradora de las historias eróticas y retorcidas de su fastuosa biblioteca. Lady Hideko siente un profundo odio por lo que su tío la obliga hacer y se tiene que valer del estafador para poder alejarse de esa realidad que la oprime. Hasta ese momento de la historia ambos personajes, Hideko y Sook-hee, no tienen definida su situación e ignoran la relación entre los tiranos y ellas mismas en el contexto. La racionalización y la reflexividad que señala Giddens no se manifiestan, lo que provoca que la agencia no se ponga en marcha. Ambos procesos llegan juntos al final de la segunda parte. Sook-hee evita que Hideko se ahorque en el árbol de durazno que años atrás había servido para el suicidio de su tía. Ese es el momento en que ambas revelan su amor y caen en la cuenta de los planes en que estaban involucradas, pues ambas estaban siendo utilizadas por el estafador y el tío Kouzuki. Esta revelación del panorama en el que se encuentran sería la racionalización de la acción: 
ahora saben cuáles son sus circunstancias, saben el rol que juega cada personaje y pueden definir lo que van hacer.

En la tercera parte del filme el accionar de los agentes se pone en marcha. Elaboran un plan de venganza contra el Conde Fujiwara y el tío Kouzuki, quienes representan el asedio masculino que reina en esa sociedad, aprovechando la vulnerabilidad que proyectan a estos hombres. El juego de apariencias sigue siendo el motor de avance en la película, pero esta vez juega en contra del estafador; Sook-hee y Hideko siguen el plan del Conde Fujiwara para poder huir a Japón fuera del alcance del tío Kouzuki. La criada es sorprendida al ser ella internada en un sanatorio en lugar de Hideko; en un principio, el plan que confabularon Sook-hee y el estafador había sido internar a su ama una vez que se casara con él, para así repartirse su fortuna. En el primer giro que tiene la historia, al final de la primera parte, se sabe el plan entre Hideko y el estafador, según el cual utilizarán a Sook-hee en reemplazo de su ama para ser internada en el sanatorio y así poder librarse del acoso de su tío. En esta última parte, sabemos que ambas protagonistas han aprovechado el plan del estafador para realizar su agencia. Sook-hee es internada, pero huye del sanatorio con la ayuda de su tía según un plan que habían desarrollado. Hideko engaña al estafador haciéndole creer que su plan ha funcionado. Para celebrarlo, le da una capa de vino con un brebaje que lo deja inconsciente. Cuando despierta es encontrado por los hombres de Kouzuko, que lo buscan por haber huido con Hideko, y lo llevan para que sea torturado por él. Ambos mueren en el siniestro sótano de Kouzuko, contaminados por las toxinas de los cigarros del supuesto Conde Fujiwara.

En las últimas escenas están ambas liberadas, disfrutando de su amor. Huyen lejos de la tierra donde fueron sometidas por una sociedad machista, en que la mujer no es considerada un individuo sino solo un medio para un fin. Cambian por mano propia su destino, y demuestran con su agencia su posición en la sociedad. El mensaje ya no es el asedio del hombre frente a la mujer; ahora la mujer se desplaza al papel de la acción, buscando su liberación y alcanzándola. Park Chan-wook demuestra la victoria de sus protagonistas gozando su sexualidad en la toma de cierre del film: están en el camarote de la nave que las lleva lejos de esa sociedad represora, ambas desnudas sobre la cama, sentadas una frente a la otra sobre sus talones, formando un solo cuerpo, acariciándose y disfrutando sonrientes de su liberación. Aquí tenemos al amor y la sexualidad como 
herramienta de acción, cuyas consecuencias inadvertidas son el encuentro de su identidad; ya no son ama y criada, ni mujeres sometidas; ahora son dos amantes iguales, sin barreras ni distancias sociales. Aceptando su amor, se aceptan a sí mismas.

\subsection{3.- Stoker: consecuencias inadvertidas}

Stoker es la primera producción de Park Chan-wook fuera de su natal Corea. En la cinta se muestra la historia de India Stoker (Mia Wasikowska), y cómo ella cambia su vida luego de la muerte de su padre en un extraño accidente de tránsito el día que cumplió dieciocho años. Richard Stoker (Delmont Mulroney) tenía una estrecha relación con su hija, y era el único que conocía los sentimientos ocultos que disimulaba el apacible comportamiento de India. El día de su funeral aparece extrañamente su hermano Charlie Stoker (Matthew Goode), del cual India nunca supo nada y supuestamente había estado viajando por Europa todos esos años. El tío Charlie tiene una personalidad encantadora, que logra seducir fácilmente a Evelyn (Nicole Kidman), la inestable madre de India. Al principio, India desconfía de él, pero poco a poco se dará cuenta que tienen muchas cosas en común, sobre todo el instinto asesino que su padre intentó que nunca aflorara.

La llegada del tío Charlie a la mansión Stoker desencadena la motivación de la acción en el proceso de agencia de India Stoker hacia la venganza. La desconfianza que le genera este misterioso familiar hace que ella en todo momento lo espíe, buscando entre sus cosas o en las de su padre para encontrar respuestas. Observa a través de las ventanas la encantadora conducta inquietante de Charlie Stoker. Descubre que muchos de los lazos que la apegaban a su padre venían en realidad por parte de su tío, como las cajas de zapatos estilo Bow-tie que encontraba en cada uno sus cumpleaños dentro de una caja blanca envuelta de un lazo amarillo. Dichos zapatos marcan todo el proceso de su crecimiento hasta su madurez; y, extrañamente, el día de su cumpleaños número dieciocho, encuentra la caja, pero esa vez solo con una llave dentro. La escena en la que India está echada en su cama con las diecisiete cajas de zapatos alrededor suyo señala la presencia de su tío desde su nacimiento, y la hace caer en cuenta del estrecho vínculo que tiene con él. India hace la conexión al encontrar la misma caja con el lazo amarillo mientras revisa las cosas de su tío. 
La actitud sospechosa del tío Charlie, siempre pendiente de lo que hace India, sugiere lo mucho que la conoce en las acciones que toma con ella. Deja indicios de los asesinatos que comete para que solo India los encuentre, y provoca que aflore el mismo instinto asesino en su sobrina, para seducirla con la muerte. A su llegada, el ama de llaves desaparece misteriosamente; ese mismo día, Charlie y Evelyn salen a pasear y vuelven con las compras de la cena. Charlie trae helado para India, de los sabores que a ella le gustan, y lo sabe sin habérselo preguntado. Le pide a su sobrina que los lleve al congelador del sótano, donde finalmente encontrará el cadáver de la Sra. McGarrick, el ama de llaves desaparecida desde el funeral. Park Chan-wook arma las atmósferas con un aire de misterio y seducción, entonando el mismo rol que asume el tío con su sobrina, dejándola descubrir de a pocos lo mucho que se parecen.

Es en este tránsito de descubrimiento donde las motivaciones se van formando; la personalidad del tío Charlie cala en el inconsciente de India, atrayéndola hacía la confusión de lo que ella es. Dos escenas marcan esos momentos: la primera, cuando ambos tocan el piano entrando en un trance de seducción. India está sentada frente al piano con los pensamientos puestos en lo que va descubriendo de su tío; se siente atraída por él. Comienza a tocar el instrumento y entra su tío en la escena para tocar con ella (hasta ese momento él no sabía tocar el piano). La música que tocan crea una atmósfera hipnotizante, que excita a India junto con los movimientos que su tío hace para tocar y cautivarla; la deja atónita al dejar de tocar abruptamente con una sonrisa confiada, satisfecho por lograr lo que quería inspirar en su sobrina.

La otra escena trascendental para entender la relación entre tío y sobrina, y cómo este la empuja a que aflore lo siniestro que habita en ella, ocurre después de que asesinan y entierran al compañero de escuela de India en el bosque. Llegan a la casa juntos después de realizar el crimen, e India entra a la ducha para quitarse las marcas de su crimen. Mientras se está duchando, se muestra por medio de flashbacks cómo el tío Charlie asesina a Whip, rompiéndole el cuello con la correa del padre de India; se muestra el movimiento del cuerpo hasta ser enterrado junto a la tía Gwendolyn Stoker, quien también había sido asesinada por Charlie estrangulándola con la misma correa. Todas estas imágenes producen dolor en India, pero se van transformando en imágenes que la excitan; se masturba pensando ellas, en una mezcla de gemidos y llanto, hasta volverse 
solo gemidos que se disuelven junto a una transición en negro. El mal aflora en India Stoker junto a la pérdida de su inocencia.

Es luego de ese momento en la historia que India tiene consciencia de su accionar; encuentra el sentido de la relación con su padre y sus días de cacería en compañía de él; comprende la relación con lo que su tío buscaba en ella. Mientras le cepilla el pelo a su madre le cuenta cómo su padre le enseñó a estar quieta para cazar; le dice "Siempre creí que a papá le gustaba cazar, pero esta noche me he dado cuenta de que lo hacía por mí. Solía decir, a veces tienes que hacer algo malo para evitar hacer algo peor". Con esta frase, India se vuelve consciente de lo que ha hecho, y ahora sabe por qué hace las cosas. Entiende lo que su padre siempre quiso evitar en ella. Estos sucesos son lo que motiva a India a actuar, confirmando lo que afirma Giddens acerca de la racionalización de la acción. El individuo de la agencia sabe cuáles son sus circunstancias y el porqué de sus acciones.

El monitoreo reflexivo y la racionalización de la acción se van presentando de forma conjunta. India sabe que el mal está dentro de ella, pero aún no ha asesinado ni sabe el verdadero motivo de la muerte de su padre. Revisa el estudio de su padre, y encuentra el cajón que abre la llave que encontró en la caja de zapatos al inicio de la película. Es un cajón del escritorio de su padre, donde guardaba las cartas que le enviaba su tío Charlie durante todos los años que no supo de él. Este suceso da inicio al clímax de la historia: India sabe que su tío estuvo recluido todos esos años en un sanatorio mental por las postales que le enviaba. Al decírselo, este le confesó que fue por matar a su hermano menor, cuando era solo un niño. También le revela que asesinó a su padre porque no quería que se acercara a su hija. En ese momento saca de su maletín la caja de zapatos que India había visto buscando entre sus cosas; dentro de la caja hay zapatos de taco que le coloca en reemplazo de sus inocentes zapatos bow-tie. La madurez representa la maldad en India, y ahora sabe el rol que juegan los demás actores.

Al enterarse de que su tío es el asesino de su padre, la relación se fortalece; la complicidad entre ambos va más allá del encubrimiento de los asesinatos, y parece estar trasladándose al plano sentimental. Esto hace que la relación con la madre se deteriore más, al punto de trastornarla y de que queme todos los animales disecados cazados por India en las excursiones de cacería con su padre. Nota las intenciones de Charlie con 
India, y le pide que se aleje de su hija; le insinúa sus sospechas sobre la muerte de su esposo y la desaparición de la tía Gwendolyn. India escucha la conversación junto al piano pensativa. Charlie se saca la correa tras escuchar las afirmaciones de Evelyn y la ataca para estrangularla; la acción violenta contra su madre hace que India tome el rifle de caza de su padre. Con los gritos de su madre y el llamado de su tío, India aparece en la imagen desenfundando el arma; aparecen insertos de ella con su padre en el terreno de caza, mostrados frecuentemente en el film. El suspense lo genera el disparo de India a un pájaro que está en su mira; en el inserto su padre voltea a verla esperando que no lo haga. Finalmente se da el disparo que atina al pájaro, en analogía con la intención de atinarle a la cabeza de su tío, asesinándolo.

La discusión que mantiene el tío Charlie con Evelyn forma parte del monitoreo reflexivo, hecho que aclara la decisión de India de salvar la vida de su madre asesinando a su tío Charlie. Luego de dispararle a su tío, arrastra su cadáver por la casa y lo entierra en el bosque, al lado de Whip y su tía Gwendolyn. Toma sus cosas en una pequeña maleta y deja a su madre para seguir con su vida. El acto de la venganza se cierra con la muerte de su tío. India Stoker construye su agencia hacia la madurez, descubriendo la plenitud de sí misma a través del descubrimiento del mal: la atracción que siente por su tío a pesar que desconfió de él, así como su complicidad y la pérdida de su inocencia demostrada en la escena de la ducha. Encuentra así la esencia de ella misma, y deja de lado a su madre para encontrar su instinto asesino al matar a su tío. Es el recorrido de India Stoker en la agencia de su propio reconocimiento a través de la venganza.

La última escena demuestra la transformación de India, cuando es detenida por el sheriff por exceso de velocidad. Habla con el oficial y demuestra que ya no es la chica tímida e introvertida que aparentaba ser. Ahora la actitud ha cambiado, la confianza es lo que la define; toma en parte el mismo encanto siniestro de su tío Charlie, y con su misma frialdad clava unas tijeras de poda en la yugular del sheriff. El oficial se arrastra por los matorrales que están al lado de la carretera tratando de salvar su vida; es ahí cuando toma sentido la reflexión de India que se muestra al inicio del filme: "Al igual que una flor no elige su color, no somos responsables de aquello en lo que nos convertimos. Solo cuando te das cuenta de esto llegas a ser libre. Hacerse adulta es ser libre". El color blanco de las flores se tiñe de rojo por la sangre del sheriff. La escena termina con India apuntando con el rifle de su padre a su moribunda víctima, disfrutando su manera de vivir la libertad. 


\subsection{4.- Lady Vengeance}

Durante los trece años que Geum-ja (Lee Young-ae) pasa en prisión, planea la venganza contra Mr. Baek (Choy Min-sik), quien años atrás la raptó junto con el niño Park Won-mo, para terminar con su vida. Baek chantajea a Geum-ja con matar a su recién nacida hija si no se inculpa por la muerte del menor. Tras su liberación, pone en práctica un elaborado plan de venganza, con el cual espera lograr su reivindicación y el perdón que busca por sus malos actos pasados. Sin embargo, el inicio de su agencia se da desde que está cumpliendo su condena; se muestra su historia mientras ayuda a muchas de las reclusas, quienes la ayudarán al salir de prisión en perjuicio de Mr. Baek. Cada una cumplirá un rol en el accionar de Geum-ja para que pueda lograr su objetivo.

En la puesta en escena de Lady Vengeance, las motivaciones se muestran a través del inconsciente de Geum-ja, en la representación de sus sueños. Enciende unas velas rojas que están sobre su tocador, en frente de un espejo de tres cuerpos, que a cada lado tiene pegado un afiche: a un lado está la foto de su hija que tuvo que dar a adopción por un crimen que no cometió, y al otro un retrato dibujado de ella cuando fue identificada por ese crimen. Luego, de rodillas frente al tocador, comienza a rezar para quedarse dormida. Casi de inmediato pasa a un sueño: en un paraje montañoso y gris, Geum-ja aparece arrastrando por la nieve lo que parece ser un caballito mecedor. Lo arrastra del cuello ayudada por una cuerda; la figura toma forma y se reconoce la cabeza de Mr. Baek. Tiene el cuerpo de un lobo que está sobre una estructura que parecen los rieles de un trineo. Ella se detiene y saca un revolver de doble gatillo y lo apunta a la cabeza a ese hombre-bestia. Este le saca la lengua como un perro le demuestra alegría a su amo. Ella contempla con alegría el gesto y dispara. El cuerpo animal se mueve por reflejo un momento, y ella es inundada por una satisfacción que no puede contener.

La racionalización y el monitoreo reflexivo del individuo se muestran en su conocimiento sobre en quién puede confiar, y en su accionar al margen de la ley. Las personas que la apoyarán en su venganza son ex convictas como ella, a excepción del detective Choi, quien siempre supo de su inocencia en el asesinato. A pesar de que el 
detective es un representante de la ley, no la obliga a demostrar su inocencia por la vía legal, dándole libertad en su capacidad de acción. Desconfía del predicador que la ayudo en prisión y la adulaba diciéndole sobre el carácter angelical que irradiaba, con la finalidad de tenerla bajo la vigilancia y el control de Mr. Baek. La protagonista le sigue el juego durante los años que está encerrada, consciente de que debe aparentar bajo las circunstancias en las que se encuentra.

Parte de su agencia es buscar su reivindicación, primero con los padres del niño que raptó años atrás y que perdió la vida. Los busca para pedirles disculpas y se corta un dedo en señal de su arrepentimiento. Lo segundo es encontrar a su hija dada en adopción; ayudada por una de las amigas que hizo en la cárcel logra saber que vive en Australia, y viaja para conocerla. Al volver a Corea, se ve forzada de volver con su hija, quien amenazó con matarse si no la dejaban ir con su verdadera madre. Este acto se describiría como una consecuencia no buscada dentro del modelo estratificado del agente que postula Giddens. Sin embargo, el retorno de la hija a Corea logra que Geum-ja pueda conseguir su redención. 


\section{AD}

\section{DISCUSIÓN}

\section{Discusión de la importancia de la investigación}

El estudio de la filmografía de Park Chan-wook es un tema ya abordado desde diferentes perspectivas; no obstante, la importancia del trabajo que aquí se presenta estriba en el análisis específico de las mujeres vengativas del mencionado autor. Se trata de un tema de importancia en el actual contexto cinematográfico, por profundizar en el estudio de la obra de uno de los directores con mayor acogida en los festivales más importantes del mundo en los últimos años, e influyente dentro de la gama de directores que representan al Nuevo Cine coreano. El abordaje de la temática de la mujer vengativa en el cine Park Chan-wook es un tema pocas veces estudiado con meticulosidad. Se contribuye a brindar una perspectiva novedosa y de interés para la comunidad académica, y se aporta al avance y consolidación del conocimiento existente. Se amplía así la escasa literatura contemporánea en lengua castellana, tema no poco importante, ya que la de habla inglesa es la más accesible por la variedad y profundidad en el estudio de los temas relacionados con la obra de nuestro director. Es una contribución así a la universalidad de nuestro idioma. Se contribuye también a que la literatura coreana deje de ser inaccesible para muchos investigadores por las limitaciones comunes que implica la relativamente escasa difusión de esa lengua. 


\section{Discusión de los Resultados}

Dentro de los directores de la Nueva Ola, Park Chan-wook es uno de los que ha abordado con mayor amplitud la temática de la venganza. Según África Sardonís (2012), "Park Chan-wook es el autor que, dentro de la nueva ola del cine coreano, más ampliamente ha abordado la vendetta como planteamiento casi obsesivo a lo largo de casi toda su filmografía". La preferencia del director por representar la venganza se demuestra al observar su filmografía, en la cual se nota que la mayoría de sus filmes no solo se centran en la temática de la venganza, sino que también su predilección por la misma se acentúa con la entrega de una trilogía dedicada al tema. Muchos de los directores de la Nueva Ola han realizado filmes en torno a la venganza, y nuestra investigación ha constatado que esta temática es la predilecta dentro del grupo. No obstante, nuestro autor ha sido el único que ha profundizado tanto en el tema como para elaborar una trilogía y cuatro películas más. Él ha explorado desde diversas perspectivas la representación de la venganza en el cine coreano.

La representación de la violencia que genera la venganza tiene tres características en el cine de Park Chan-wook: primero, sus personajes siempre se mueven al margen de la ley; segundo, la venganza tiene un dominio exclusivamente personal; tercero, el cuerpo es el objeto en que se manifiesta la venganza. Esta conclusión se deduce del artículo de Kim Kyung-hyun (2006), donde se señala que las representaciones de la violencia en la Trilogía de la venganza tienen una funcionalidad narrativa que yace en los cuestionamientos existenciales de sus personajes, y no solo como muestras gratuitas de brutalidad para satisfacer a un grupo de fans; ello es lo único que inspira la violencia. En el artículo mencionado se enumera una serie características que explican el uso de la violencia como parte fundamental en la estructura de los filmes.

De las cualidades presentadas se tomaron las tres ya mencionadas, y los criterios con los que se hizo la selección fueron: en primer lugar, que partieran de un análisis netamente de implicancias cinematográficas; y en segundo lugar, que el autor no utlilizara teorías filosóficas para sustentarlas. En sus películas esas tres cualidades actúan casi como condicionantes, debido a que, si las tres no están supuestas en la manifestación de la venganza de sus personajes, esta no podría ser violenta dentro de la lógica del director. 
El protagonismo de personajes femeninos que buscan venganza es una tendencia dentro de la filmografía de Park Chan-wook. Africa Sardonís (2012) hace una comparación entre la película Bedevilled (Jang Cheol-soo, 2010), que trata la misma temática, con las características que Park Chan-wook presenta en su tratamiento de las mujeres vengativas: "Aunque muy alejada del cuidado estilo visual y del virtuosismo narrativo de Park Chan-wook, comparte el tratamiento que se le da a la figura femenina, otorgándole un protagonismo absoluto”. El enunciado de Sardonís resalta la tendencia del director, basando su interpretación en el estilo característico con que las representa. Son tres las películas dentro de su filmografía que tienen a la mujer con eje central de su historia y que cumplen el rol de vengadoras.

La mujer vengativa de Park Chan-wook tiene su origen en el subgénero de horror japonés llamado Kaibyo eiga. Durante la década de los cincuenta y sesenta, el cine japonés produjo un gran número de filmes que representaban la vuelta desde el Más Allá de mujeres en busca de venganza, en forma de espectros gato. La gran cantidad de tramas que se produjeron durante ese período de años contaban con una característica común, que describe Malpartida (2014: 34): "Dada la repetición de tramas, casi siempre en torno a la injusticia que comete el poderoso, asesinando o llevando al suicidio a una o varias personas, que en asociación espectral con un gato vuelven del Más Allá para vengarse [en todos los casos son mujeres]". La estructura que detalla Malpartida se asemeja en muchos factores a las narraciones de las mujeres vengativas de Park Chan-wook, pero se diferencian en lo temporal por el carácter sobrenatural de estas películas del Japón. Sin embargo, lo más importante entre las similitudes es el tratamiento fantástico, lleno de un aura de misterio para representar a las mujeres vengativas. Esto se aprecia con mayor énfasis en su film Stoker, donde la atmósfera intrigante que se genera alrededor de su protagonista es casi idéntica a la que varios directores del Kaibyo eiga les dan a sus mujeres espectrales en el tránsito de su venganza: solitarias, introvertidas e impredecibles.

Entre las mujeres vengativas se abre la posibilidad de la aceptación y reconocimiento de lo que las define, pues caen en cuenta de ello luego del proceso que les tomó la venganza, pero como un efecto colateral de sus acciones. Este resultado parte de la interpretación de lo afirmado por Steve Choe (2009: 31): "Park offers an 
interpretation of revenge that opens up a different logic altogether, one dictated less by punishment and payback and more by the possibility of forgiveness". Por extensión a esta afirmación, se concluye, que la implicancia de las lógicas que abren la venganza es la posibilidad de la aceptación y el reconocimiento de lo que esencialmente las define. En las tres películas objeto del estudio, la venganza les ofrece a las protagonistas, más allá de la satisfacción que les genera consumarla, la posibilidad de identificar lo que finalmente las define. En Lady Vengeance, Geum-ja, tras asesinar a Mr. Baek, se da cuenta que no han desaparecido los sentimientos de culpa que la empujaron hacia la venganza; sin embargo, tras el crimen brotan nuevamente de ella sentimientos nobles, a causa del amor que siente por su hija que consideraba perdida. El acto de la venganza hizo que reconociera su rol como una madre abnegada. En Stoker es más evidente; al asesinar a su tío Charlie para vengar a su padre, India Stoker acepta el gusto por matar, reconociendo que asesinar es parte de vivir su libertad.

El modelo estratificado del agente explica este proceso y también contempla los resultados inesperados por las acciones de los actores, los cuales, en el caso de los personajes de Park, serían la aceptación y el reconocimiento de lo que las define. Según Anhony Giddens, la agencia es la capacidad de acción del individuo para cambiar y dar forma a la sociedad (2015: 59). Señala el mismo autor que la agencia se manifiesta como un proceso que parte de lo consciente y repercute en el inconsciente, con lo cual puede ocasionar consecuencias no buscadas. El proceso se detalla en su modelo estratificado del agente, que explica las acciones de los personajes de Park Chan-wook en su camino de venganza. El autor considera dentro de su modelo la existencia de "condiciones inadvertidas de la acción" que involucran "consecuencias no buscadas", y les da importancia a las circunstancias en que se desarrollan las acciones. Explicando con ello los efectos colaterales que surgen de la venganza de las mujeres de Park Chan-wook, y permite concluir que las lógicas que abre la venganza (las circunstancias) de estos personajes, les da la posibilidad del reconocimiento y aceptación de lo que esencialmente las define (es decir, consecuencias no buscadas). En conclusión, se puede afirmar que las diferentes lógicas que surgen por la venganza abren la posibilidad de la aceptación y reconocimiento de lo que define a las mujeres del cine de Park Chan-wook, y se sostiene lo afirmado por la teoría de la agencia del sociólogo Anthony Giddens. 


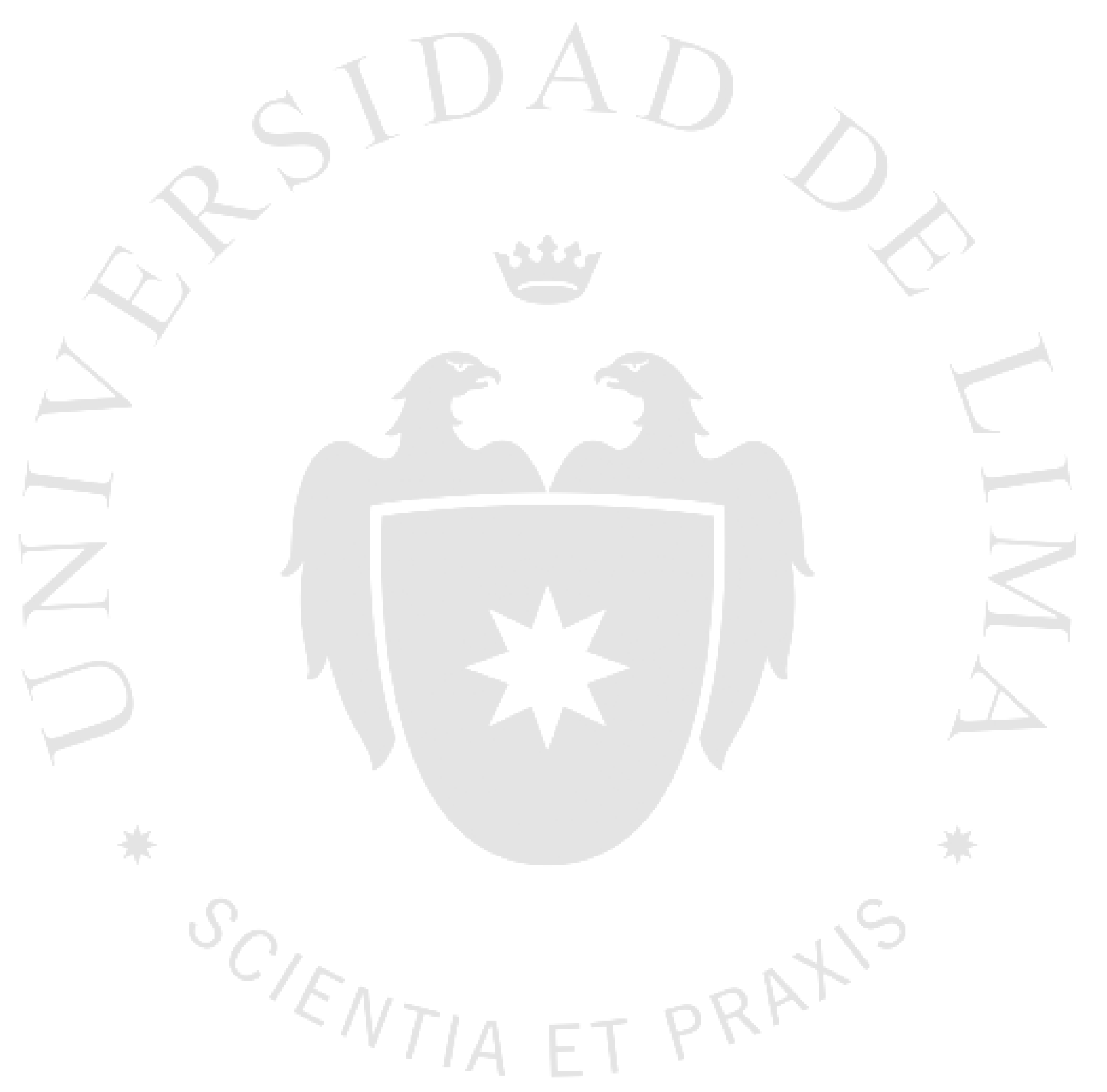




\section{BIBLIOGRAFÍA}

Altman, Rick.

2001

Los géneros cinematográficos. Barcelona: Paidós.Álvarez, María del Pilar

2012

"El cine coreano contemporáneo"; en Pul (setiembre): 50-52. En Internet:

https://www.academia.edu/8318271/Cine_coreano_contempor $\%$ C3\% A1neo

Atom

2005 Géneros Cinematográficos: clasificación de los productos de la industria del cine. [Blog]. Recuperado de:

http://codigosvisuales09.blogspot.pe/

Balló, Jordi, y Xavier Pérez

1995 La semilla inmortal: los argumentos universales en el cine. Barcelona: Anagrama.

Choe, Steve

2009

"Love your enemies: Revenge and forgiveness in films by Park Chanwook"; en Korean Studies 33: 29-51,167. En Internet:

http://fresno.ulima.edu.pe/ss_bd00102.nsf/RecursoReferido?OpenFor m\&id=PROQUEST -

41716\&url=/docview/220296455?accountid=45277

Conrich, Ian

2010

"Gothic Bodies and the return of the repressed: the Korean films of Ahn Byeong-ki”; en Gothic Studies (12) 1: 106-115.

Garcelán, Enrique, y Gloria Fernández 

Corea Argentina, Universidad de Buenos Aires En Internet (agosto, 2011): http://www.uba.ar/ceca/newsletters/agosto_11/nl-nota1.php

Giddens, Anthony 1995 La constitución de la sociedad, bases para la teoría de la estructuración (3a ed.). Buenos Aires: Amorrortu.

Giddens, Anhony, y Philip W. Sutton

2015 Conceptos esenciales de sociología. Madrid: Alianza Editorial.

Gurpegui, Carlos

2014 El thriller coreano y la hibridación genérica. Sakuyaki Asian Cinema. En Internet: https://harlanmagazine.com/2014/10/07/el-thrillercoreano-y-la-hibridacion-generica/

Shin Jee-young

Globalization and New Korean Cinema: New Korean Cinema. Edinburgh: Edinburgh University Press.

Kim Kyung-hyun

2006

"Tell the kitchen that there's too much buchu in the dumpling: Reading Park Chan-wook's "Unknowable"”; en Korean Journal 46, 1: 84-109.

Malpartida, Rafael

2014 Espectro de cine en Japón: entre la literatura, la leyenda y las nuevas tecnologías. Gijón: Editorial Satori.

Martínez, Jordi

2010 El "cine asiático" como género: problemas de definición. Capítulo 11PDF. Cruce de miradas, relaciones e intercambios 3: 175-188. En Internet:

http://s3.amazonaws.com/academia.edu.documents/33934095/capitulo 11.pdf?AWSAccessKeyId=AKIAJ56TQJRTWSMTNPEA\&Expires= 1479143175\&Signature $=$ UNVs73w7yskFyT\%2Bu5kKzWQfheKo\%3 
D\&response-content-

disposition=inline \%3B\%20filename\%3DCAPITULO_11.pdf

Reyes, L., Ribeiro, E., Bravo, J., Bettini, M.

2010

"Rojo Almodóvar"; en Proyectos Jóvenes de Investigación y Comunicación 36: 39-42. En Internet:

http://fido.palermo.edu/servicios_dyc/publicacionesdc/vista/detalle_pu blicacion.php?id_libro=322

Romney, Jonathan

2006 "Sympathy for the devil"; en Artforum International 44: 271-274, 277.

En Internet:

http://fresno.ulima.edu.pe/ss_bd00102.nsf/RecursoReferido?OpenFor

$\mathrm{m} \& \quad \mathrm{id}=$ PROQUEST- 41716 \&

url=/docview/214351286? accountid=45277

Rubens, Martin

2000

Thrillers. Madrid: Cambrige University Press.

Sandonís, África

2012 "La venganza, en el cine coreano, se cocina en el infierno"; en El espectador imaginario 35 (Setiembre) [fecha de consulta: 14 noviembre 2016]. En Internet: http://www.elespectadorimaginario.com/lavenganza-en-el-cine-coreano-se-cocina-en-el-infierno/ . ISSN 2013$438 \mathrm{X}$

Shin Chi-yun y Julian Stringer (eds.)

Putting Korean Cinema in its place: Genre Classifications and the contexts of Reception. New Korean Cinema. Edinburgh: Edinburgh University Press. 


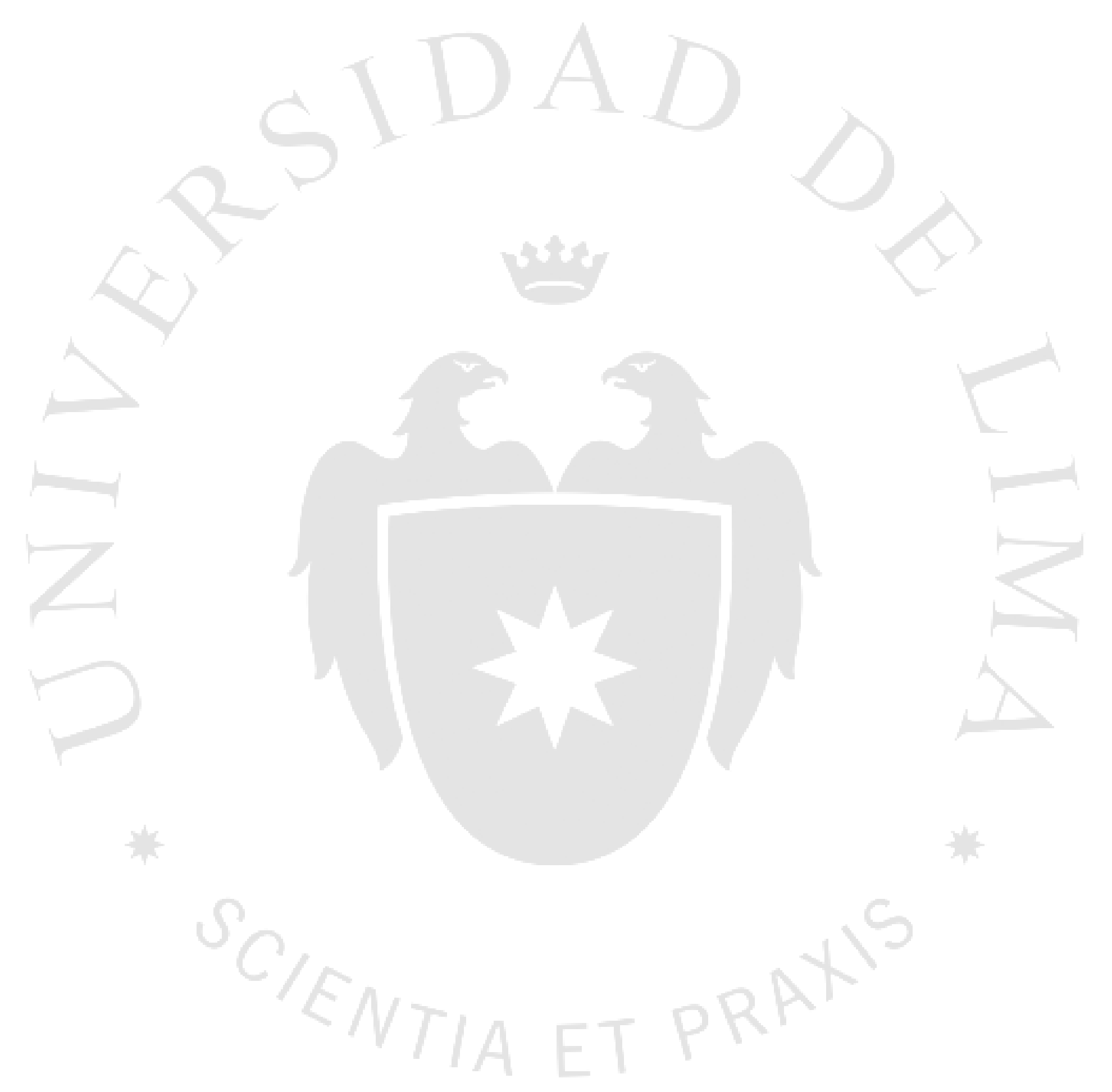

71 